
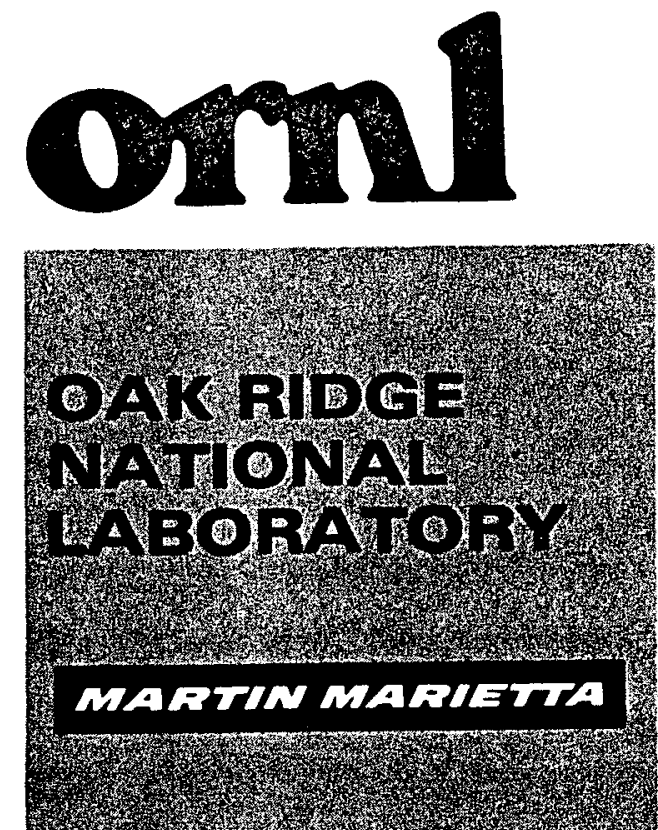

\title{
Solvent Extraction Studies with Intermediate-Burnup fast Flux Test Facility Fuel in the Solvent Extraction Test Facility
}

ORNL/TM-9514

D. E. Benker

J. E. Bigelow

W. D. Bond

F. R. Chattin

L. J. King

F. G. Kitts

R. G. Ross

R. G. Stacy

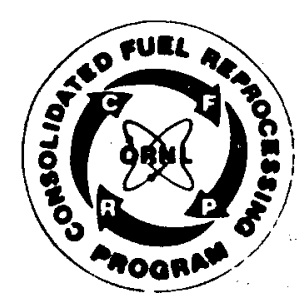




\section{DISCLAIMER}

This report was prepared as an account of work sponsored by an agency of the United States Government. Neither the United States Government nor any agency Thereof, nor any of their employees, makes any warranty, express or implied, or assumes any legal liability or responsibility for the accuracy, completeness, or usefulness of any information, apparatus, product, or process disclosed, or represents that its use would not infringe privately owned rights. Reference herein to any specific commercial product, process, or service by trade name, trademark, manufacturer, or otherwise does not necessarily constitute or imply its endorsement, recommendation, or favoring by the United States Government or any agency thereof. The views and opinions of authors expressed herein do not necessarily state or reflect those of the United States Government or any agency thereof. 


\section{DISCLAIMER}

Portions of this document may be illegible in electronic image products. Images are produced from the best available original document. 
ORNL/TM-9514

Dist. Category UC-86T

(Applied)

\section{Consolidated Fuel Reprocessing Program}

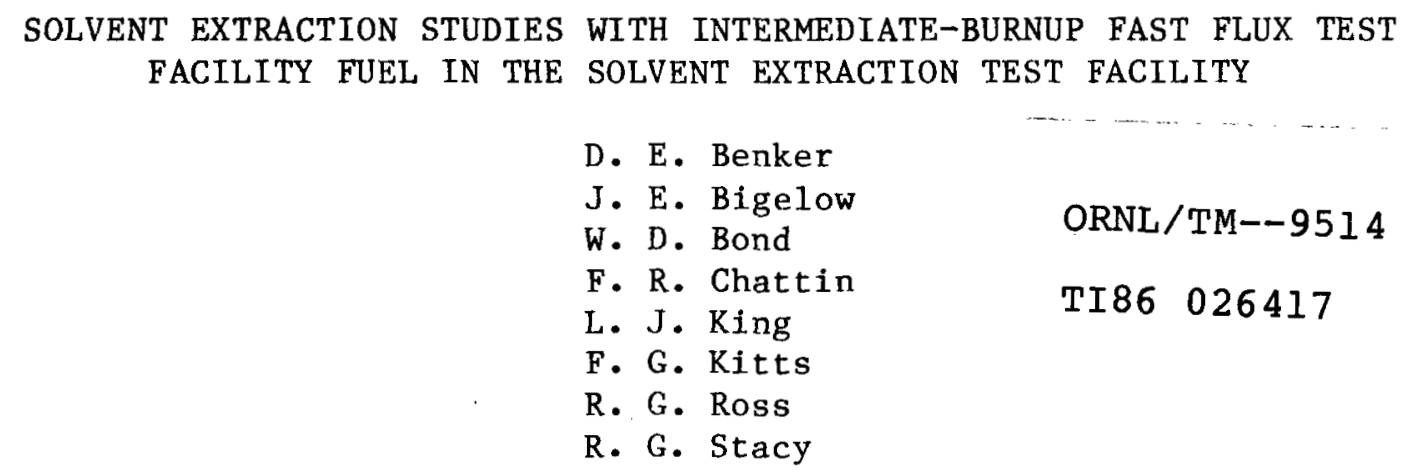

Chemical Technology Division

Date Issued - April 1986

NOTICE: This document contains information of a preliminary nature. It is subject to revision or correction and therefore does not represent a final report.

Prepared by the OAK RIDGE NATIONAL LABORATORY

Oak. Ridge, Tennessee 37831 operated by MARTIN MARIETTA ENERGY SYSTEMS, INC. for the U.S. DEPARTMENT OF ENERGY under Contract No. DE-AC05-840R21400 


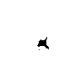

.
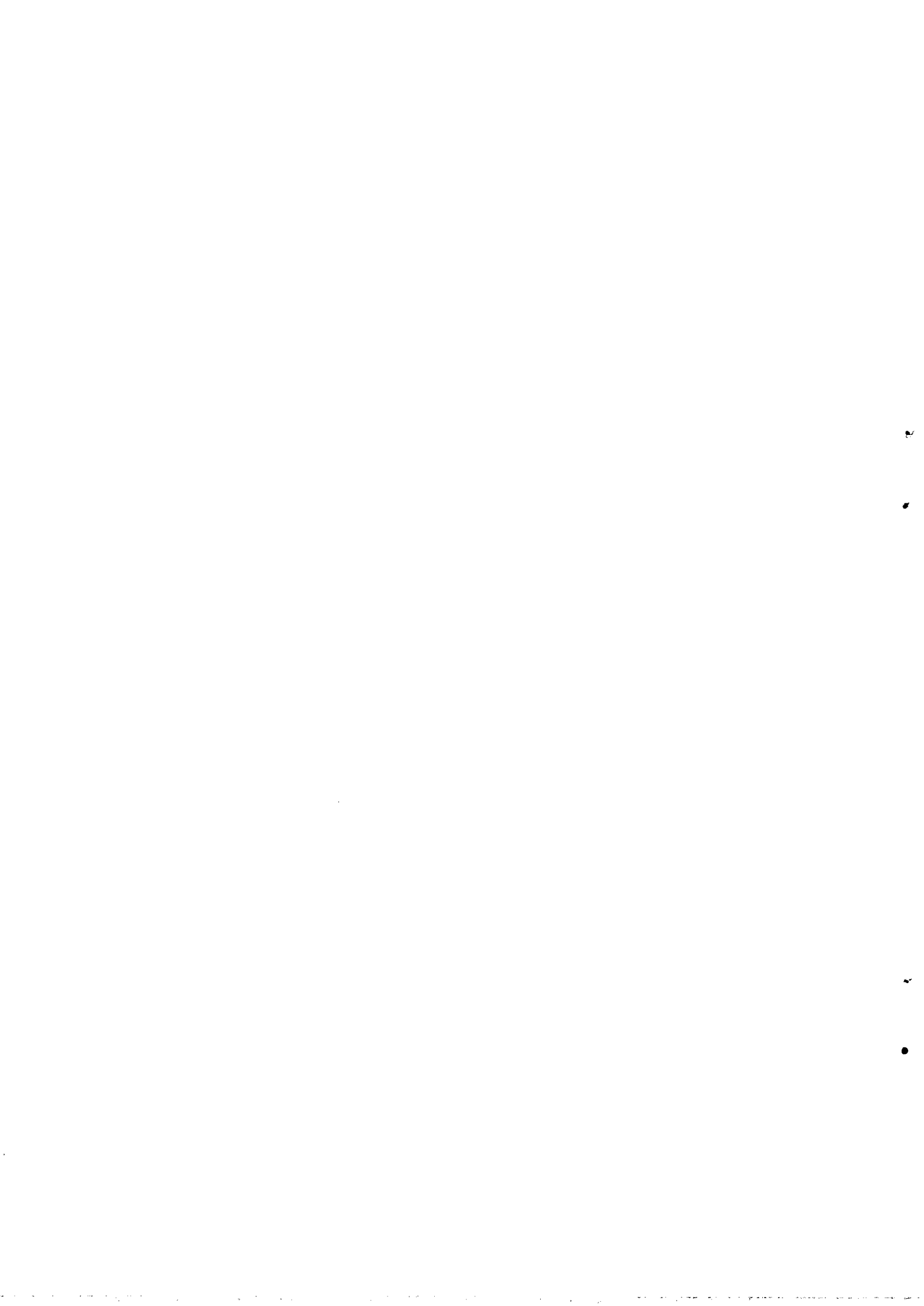
CONTENTS

Page

LIST OF FIGURES . . . . . . . . . . . . . . . . . . . . v

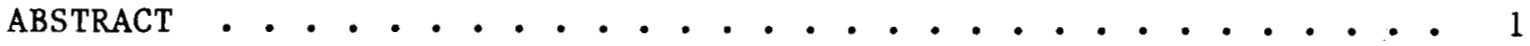

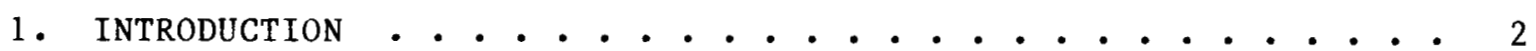

2. EQUIPMENT AND OPERATIONAL PROCEDURES . . . . . . . . . . . 3 2.1 IN-LINE PHOTOMETER . . . . . . . . . . . . . . . . . 4

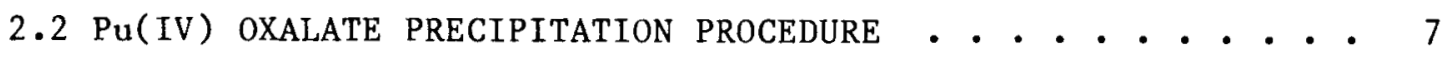

3. DESCRIPTION OF SOLVENT EXTRACTION FLOWSHEETS..$\cdots$. . . • 8

4. EXPERIMENTAL RESULTS AND DISCUSSIONS OF SOLVENT EXTRACTION

TESTS . . . . . . . . . . . . . . . . . 8

4.1 RESULTS FROM THE COEXTRACTION-COSCRUBING CONTACTOR . . . . 11

4.2 RESUltS FROM THE PARTITIONING AND STRIP CONTACTORS . . . 16

4.2.1 Organic Backscrub .............. 16

4.2.2 Selective Uranium Extraction .......... . 19

4.2.3 Zirconium and Ruthenium ............ 24

4.3 RESUlTS FROM THE IN-LINE PHOTOMETER . . . . . . . . . 26

5. PLUTONIUM PURIFICATION AND CONVERSION TO OXIDE....... .28

6. SUMMARY AND CONCLUSIONS . . . . . . . . . . . . 32

7. ACKNOWLEDGMENTS . . . . . . . . . . . . . . 33

8. REFERENCES . . . . . . . . . . . . . . . 34

APPENDIX A . . . . . . . . . . . . . . . . . 37 


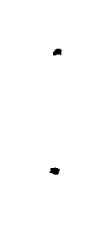


1 In-11ne photometer system for the SETF . . . . . . . . 5

2 FFTF solvent extraction flowsheet used for Run 8-1 using the organic backscrub method for partitioning . . . . . 9

3 FFTF solvent extraction flowsheet used for Run 8-3 using the selective uranium extraction method of partitioning . 10

4 Concentration profiles for ${ }^{95} \mathrm{Zr}$ and ${ }^{106} \mathrm{Ru}$ in the extractionscrubbing contactor for Runs 8-1 and 8-3........ 13

5 Organic-phase profiles for uranium and plutonium in the extraction-scrubbing contactor for Runs 8-1 and 8-3 . . . 14

$6 \quad$ Organic-phase profiles for ${ }^{95} \mathrm{Zr}$ and ${ }^{106} \mathrm{Ru}$ in Runs $8-1$ and 8-3 ................... . . 15

7 Concentration profiles of plutonium in the partition contactor for Runs 7-3B and 8-1 . . . . . . . . . . 17

8 Concentration profiles of uranium in the partition contactor for Runs 7-3B and 8-1 . . . . . . . . . 20

9 Concentration profiles of plutonium and uranium in the costrip contactor for Runs 7-2 and 8-3 ......... 21

10 Concentration profiles of plutonium in the partition contactor for Runs 7-2 and 8-3 .......... 22

11 Concentration profiles of uranium and nitric acid in the partition bank for Runs 7-2 and 8-3 . . . . . . . . 23

12 Sample results and photometer readings from Run 8-2 . . . 27

13 Concentration readings from the coextraction-coscrub bank in Run 8-3, using the in-line alpha monitor and the in-line photometer.

.. .

\section{DISCLAIMER}

This report was prepared as an account of work sponsored by an agency of the United States Government. Neither the United States Government nor any agency thereof, nor any of their employees, makes any warranty, express or implied, or assumes any legal liability or responsibility for the accuracy, completeness, or usefulness of any information, apparatus, product, or process disclosed, or represents that its use would not infringe privately owned rights. Reference herein to any specific commercial product, process, or service by trade name, trademark, manufacturer, or otherwise does not necessarily constitute or imply its endorsement, recommendation, or favoring by the United States Government or any agency thereof. The views and opinions of authors expressed herein do not necessarily state or reflect those of the United States Government or any agency thereof. 
SOLVENT EXTRACTION STUDIES WITH INTERMEDIATE-BURNUP FAST FLUX TEST FACILITY FUEL IN THE SOLVENT EXTRACTION TEST FACILITY

D. E. Benker, J. E. Bigelow, W. D. Bond, F. R. Chattin, L. J. King, F. G. Kitts, R. G. Ross, and R. G. Stacy

\section{ABSTRACT}

In Campaign 8 , two batches of irradiated fuel from the Fast Flux Test Facility (FFTF) were processed, using $30 \%$ $\mathrm{TBP}-\mathrm{NPH}$, in the Solvent Extraction Test Facility (SETF). The burnups were about 36 and $55 \mathrm{MWd} / \mathrm{kg}$ with 1.3- and 1-year cooling times, respectively. The latter fuel had the highest burnup and shortest cooling time of any fuel ever handled in the SETF. No major problems were noted during the operation of the mixersettlers, and low uranium and plutonium losses $(<0.02 \%)$ were achieved. Zirconium and ruthenium decontamination factors (DFs) were improved by increasing the number of scrub stages and increasing the peak solvent loading in the coextraction-coscrub bank. The use of an in-line photometer to measure the uranium and plutonium concentrations in a process stream permitted high solvent loadings of heavy metals to be achieved in the extraction bank while maintaining low losses to the aqueous raffinate. The investigation of two flowsheet options for making separate uranium and plutonium products (organic backscrub and selective uranium extraction) that was started in Campaign 7 was continued. High-quality products were again obtained (uranium and plutonium DFs of $\left.\sim 10^{4}\right)$. Plutonium reoxidation was still extensive even though hydrazine was added to the aqueous strip for the organic backscrub flowsheet. Two different plutonium oxalate precipitation procedures [Pu(III) and $\mathrm{Pu}$ (IV)] were used in the preparation of the plutonium oxide products; this was done so that the fuel fabrication characteristics of the oxide from the two procedures could be compared. A total of $\sim 450 \mathrm{~g}$ of plutonium was recovered and shipped to the fuel refabrication program. 
1. INTRODUCTION

The SETF is located in one of the heavily shielded hot cells of the Transuranium Processing Plant at the Oak Ridge National Laboratory. 1 In this facility, mixer-settler contactors are used to evaluate solvent extraction flowsheets for the reprocessing of irradiated nuclear reactor fuels. Results from these tests provide information on heavy-metal recoveries, fission product behavior, comparisons of flowsheet options, evaluation of in-line instrumentation, and general operability of the system.

Previous work in Campaigns $1-6^{1-4}$ had concentrated on the study of Purex-based reprocessing methods that emphasized coprocessing, that is, only partially separating the uranium from the plutonium. However, recent studies of proposed reprocessing plants, such as the Breeder Reprocessing Engineering Test (BRET) facility, have assumed preparation of separate uranium and plutonium products. As a result, the emphasis was changed during Campaign 7 to methods ${ }^{5}$ that completely partition the uranium and plutonium recovered from FBR fuels. The broad objective of studying procedures for reprocessing FFTF fuels was continued in the most recent work, Campaign 8, using fuels of higher burnups and shorter cooling times than in previous campaigns.

The fuel used in Campaign 8 came from two different FFTF fuel assemblies, DE-1-6 and DE-2-1R, which had been irradiated to $\sim 36$ and $\sim 55 \mathrm{MWd} / \mathrm{kg}$, and had been discharged in November 1982 and May 1983, respectively. For each batch of fuel, the processing steps included: (1) dissolution of the fuel in nitric acid; (2) filtration and adjustment of the dissolver solution to the proper feed conditions for solvent extraction; (3) a solvent extraction test, using $30 \% \mathrm{TBP}-\mathrm{NPH}$, with total partitioning in the mixersettlers; (4) anion exchange to purify the plutonium product; (5) plutonium oxalate precipitation; and (6) calcination of the oxalate product to plutonium oxide.

Three solvent extraction experiments were completed; two of these (8-1 and 8-3) were made using the two fuels described above, respectively, and the third (8-2) was made using depleted uranium as feed to test the new1y installed in-line photometer system prior to using it in a run (8-3) with irradiated fuel. The photometer was used to measure the uranium and 
plutonium concentrations in the solvent from a stage in the coextractioncoscrub contactor, and the solvent flow rate was adjusted to maintain the plutonium (or uranium) concentration within a desired range.

As in Campaigns 5 and 7 , the recovered plutonium from each batch of fuel was sent to the Hanford Engineering Development Laboratory (HEDL) for use in fuel fabrication studies. Two different oxalate precipitation procedures that yielded either a $\mathrm{Pu}(\mathrm{III})$ or a $\mathrm{Pu}$ (IV) oxalate product were used. This was done so that a comparison of the fuel fabrication characteristics of the oxides from the two procedures could be evaluated. A total of $450 \mathrm{~g}$ of plutonium was prepared for shipment to the HEDL.

\section{EQUIPMENT AND OPERATIONAL PROCEDURES}

Most of the major equipment items and general operating procedures used in Campaign 8 were similar to those for the previous campaigns. A description of the general layout and equipment and the operation of the solvent extraction contactors is given in ref. 1; the fuel dissolution and clarification steps are discussed in ref. 5, the filtration equipment in refs. 2 and 3 , and the plutonium purification and conversion to oxide in ref. 3 .

The in-line photometer system that was installed for evaluation in this campaign with irradiated FFTF fuel is briefly described in sect. 2.1. It is essentially the same system developed for use in a 500-kg/d reprocessing plant, except that a different type of sample cell was designed for use in the SETF hot cel1. "Some of the basic principles of photometric measurement of uranium and plutonium in TBP solutions are described in refs. 6 and 7 .

As mentioned in the Introduction, two different procedures were used to prepare plutonium oxalate for the conversion of the product to the oxide form. The $\mathrm{Pu}$ (III) oxalate procedure has been used previously and is described in ref. 3 ; the $\mathrm{Pu}(\mathrm{IV})$ oxalate procedure is new and is described in Sect. 2.2. The $\mathrm{Pu}(\mathrm{III})$ and $\mathrm{Pu}(\mathrm{IV})$ procedures were used with the Runs 8-1 and 8-3 plutonium products, respectively. 


\subsection{IN-LINE PHOTOMETER}

The photometer system was divided into three major parts (Fig. 1): (1) the in-line solution sample cel1, which was in the hot ce11; (2) the photometer optical unit (1ight source, photomultiplier tube, filters, etc.), which was in the Limited Access Area (LAA) just above the SETF hot ce11; and (3) the microcomputer, which was in the control room.

Process solution was pumped from a settling stage in the mixer-settler through the sample cell and back to the mixer of the next downstream stage using an FMI positive-displacement pump. In these tests the organic phase was analyzed, so a small knockout pot was included before the sample cell to remove any entrained aqueous solution; the pot was a $30-\mathrm{mm}$-diam Pyrex test tube with a 1iquid holdup of $\sim 30 \mathrm{~mL}$. The total solvent volume in the entire sample loop (knockout pot, sample cell, and lines) was $\sim 50 \mathrm{~mL}$ and the flow rate through the loop was set at $\sim 8 \mathrm{~mL} / \mathrm{min}$. As a result, the readings from the sample loop should have lagged a few minutes behind changes in the sample stage. This delay was comparable to the residence times in the mixer-settler, which was also in the range of several minutes per stage.

The photometer optical unit and the solution sample cell were connected with fiber-optic cables that passed through the concrete shielding and permited the transmission of light signals between the sample cell and the photometer unit. Light signals were also sent through a "blank" cell with only an alr gap, and the reading from this cell was used to correct the solution readings for interferences such as radiation darkening of the fibers, particulates in the solution, films that might form on the surfaces of the sample ce11, etc. Two fibers were needed for each ce11, one to carry the light signal to the cell and a second to return it to the photometer. Each fiber was $17 \mathrm{~m}$ long with no intermediate connections between the photometer and the cell. Prior to a run, the length of the light path in the cell was adjusted within a $0.5-$ to $15-\mathrm{mm}$ range in order to optimize the instrument for its intended application. (For example, a concentrated product stream needs a much shorter path length than a dilute raffinate stream in order to get a light transmittance that is neither too strong nor too weak.) 


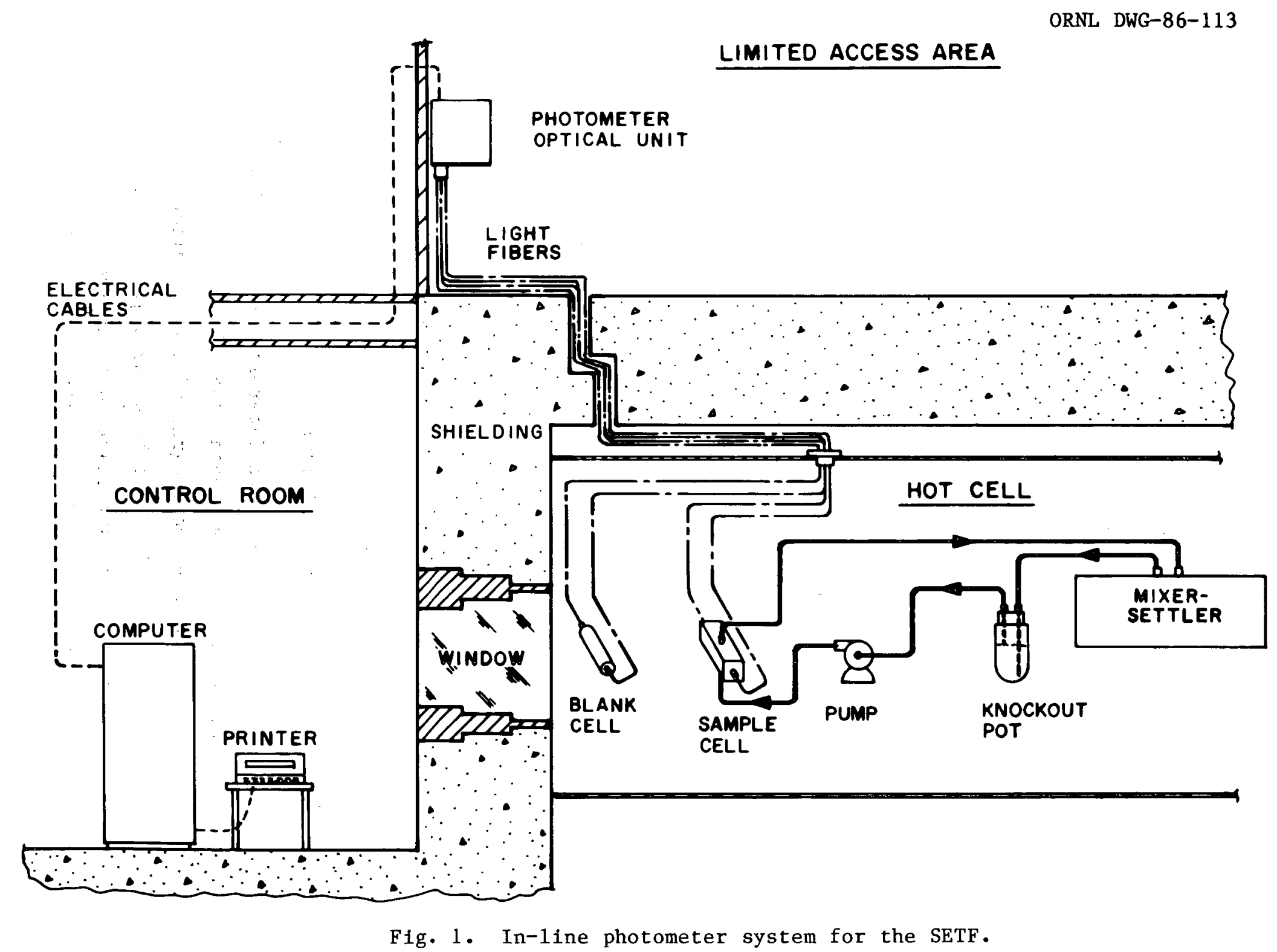

v 
The transmittance data were sent from the photometer unit to an LSI-11/23 microcomputer over conventional electrical cables, and the microcomputer was used to interpret the transmittance data and display the heavy-metal concentrations. The transmittances at four separate wavelengths were measured in both the process sample cell and in the blank cell: (1) at $426 \mathrm{~nm}$ to determine the uranium concentration, (2) at $660 \mathrm{~nm}$ to determine the $\mathrm{Pu}(\mathrm{IV})$ concentration, (3) at $833 \mathrm{~nm}$ to qualitatively check for the absence of $\mathrm{Pu}(\mathrm{VI})$, and (4) at $580 \mathrm{~nm}$ to correct the other three transmittances for miscellaneous interferences mentioned above (solids, precipitates plating in the sample cell, radiation darkening of the 1ight fibers, etc.). The transmittance data were corrected using the following formula:

$$
\mathrm{T}=\frac{\mathrm{T} \text { (samp1e) } \times \mathrm{T}_{580}(\mathrm{~b} \text { lank })}{\mathrm{T}(\mathrm{b} \text { lank }) \times \mathrm{T}_{580}(\text { sample })},
$$

where

$\mathrm{T}=$ the corrected transmittance,

$\mathrm{T}_{580}=$ the transmittance at $580 \mathrm{~nm}$.

The absorbance is then calculated as $A=-\ln (T)$.

The uranium and plutonium concentrations $(\mathrm{g} / \mathrm{L})$ were calculated from the absorbance data using the following equations:

$$
\begin{aligned}
\mathrm{Pu}(\mathrm{IV}) & =\left(\mathrm{A}_{660}-\mathrm{Cl}\right) / \mathrm{C} 2, \\
\mathrm{Pu}(\mathrm{VI}) & =\left(\mathrm{A}_{833}-\mathrm{C} 3\right) / \mathrm{C} 4, \\
\mathrm{Pu} & =\mathrm{Pu}(\mathrm{IV})+\mathrm{Pu}(\mathrm{VI}), \text { and } \\
\mathrm{U} & =\left[\mathrm{A}_{426}-\mathrm{C} 5[\mathrm{Pu}(\mathrm{IV})]-\mathrm{C6}\right] / \mathrm{C} 7 .
\end{aligned}
$$

The coefficients, $\mathrm{Cl}$ through $\mathrm{C} 7$, were determined by measuring calibrated solutions just prior to the experimental run.

The microcomputer may also be programmed with an algorithm for contro1ling the heavy-metal loading in the solvent by adjusting the flow rate of a reagent stream (the organic extractant, $\mathrm{HAX}$ ) to the mixer-settler. However, computer control was used only briefly toward the ends of Runs 8-2 and 8-3 to serve as a test to gain some operating experience with this new control system. 


\subsection{Pu(IV) OXALATE PRECIPITATION PROCEDURE}

The processing conditions were modeled from those described in a report by Harmon and Reas. ${ }^{8}$ The feed was the plutonium product solution from an anion exchange purification run, which had been collected into about ten 1-L polyethylene bottles. The plutonium concentrations in these bottles ranged from 1 to $50 \mathrm{~g} / \mathrm{L}$, and the free acid concentrations ranged from 0.7 to $7.5 \mathrm{M}$. The product bottles were not composited before the oxalate precipitation. Appropriate fractions were taken from the bottles to provide a feed that was roughly the same for each run $(22.5 \mathrm{~L}$ of solution containing $\sim 50 \mathrm{~g}$ of plutonium and five equivalents of acid).

The precipitations were carried out in a 4.5-L glass vessel, which was described in the Campaign 5 report. ${ }^{3}$ The $\mathrm{Pu}(\mathrm{IV})$ precipitation procedure consisted of the following steps:

1. A total of $2.5 \mathrm{~L}$ of the plutonium feed solution was transferred from the polyethylene bottles to the precipitation vessel. The bottles were flushed to the vessel with a total of $\sim 0.5 \mathrm{~L}$ of $2 \underline{\mathrm{M}} \mathrm{HNO}_{3}$ solution.

2. The agitator 1 the vessel was set to $1000-2000 \mathrm{rpm}$, and the solution was heated to $55 \pm 5^{\circ} \mathrm{C}$.

3. When the solution was at temperature, $1.1 \mathrm{~L}$ of $0.8 \mathrm{M}$ oxalic acid and $0.15 \mathrm{~L}$ of $30 \% \mathrm{H}_{2} \mathrm{O}_{2}$ were combined in a metering tank and transferred to the precipitation vessel at the rate of 1 to $2 \mathrm{~L} / \mathrm{h}$. The addition system was flushed to the precipitation vessel with $0.4 \mathrm{~L}$ of $2 \mathrm{M} \mathrm{HNO}_{3}$ -0.1 M oxalic acid solution.

4. The solution in the vessel was held at $55 \pm 5^{\circ} \mathrm{C}$ for 30 additional minutes, then cooled to ambient temperature $\left(\sim 30^{\circ} \mathrm{C}\right)$ and filtered.

5. The precipitation vessel and the precipitate cake in the filter were washed with three batches of $0.5 \mathrm{~L}$ of $2 \underline{\mathrm{M}} \mathrm{HNO}_{3}-0.1 \mathrm{M}$ oxalic acid solution.

6. The first precipitation product was left in the filter while steps 1 through 5 (above) were repeated for a second batch precipitation. This second product was added on top of the first.

7. The calcination was then accomplished by removing the filter (Inconel body with a fritted-bottom platinum liner), placing it in an electrically heated furnace, and heating at $500^{\circ} \mathrm{C}$ for $2 \mathrm{~h}$. 


\section{DESCRIPTION OF THE SOLVENT EXTRACTION FLOWSHEETS}

The investigation of two first-cycle flowsheet options that was begun in Campaign 7 was continued in Campaign 8. Schematics of the flowsheets with the operating conditions used in Campaign 8 are shown in Figs. 2 and 3; detailed descriptions of the Campaign 7 flowsheets are given in ref. 5 . Conditions that remained unchanged from Campaign 7 included: (1) the same organic solvent, 30 vo1 \% tri-n-buty1 phosphate (TBP) diluted with a normal paraffin hydrocarbon (NPH); (2) the dual acid scrubs in the coextractioncoscrub contactor, HAS $\left(0.5 \mathrm{M}^{\mathrm{HNO}} 3\right)$ and $\mathrm{HAIS}\left(5.0 \mathrm{M} \mathrm{HNO}_{3}\right)$; (3) the use of hydroxylamine nitrate (HAN) to reduce plutonium to the poorly extractable $\mathrm{Pu}$ (III) species; and (4) the partitioning methods for separating uranium and plutonium, organic backscrub (the method traditionally used in the Purex process) in Runs $7-3 B$ and $8-1$ or selective uranium extraction in Runs 7-2 and 8-3.

Significant changes for Campaign 8 included: (1) increasing the number of scrub stages in the coextraction-coscrub mixer-settler, (2) increasing the solvent loading in the coextraction-coscrub bank (Run 8-3), and (3) adding hydrazine to the organic backscrub partitioning method (Run 8-3). operating conditions and detailed stream analyses for each run are tabulated in the Appendix.

\section{EXPERIMENTAL RESULTS AND DISCUSSIONS OF SOLVENT EXTRACTION TESTS}

The FFTF fuels processed during Campaign 8 had much higher burnups (14 to 25 times) and shorter cooling times ( $50 \%)$ than the fuel used in Campaign 7; as a result, the fission product activity in the feed was much greater (Table 1). The short cooling times allowed easy detection of $95 \mathrm{Zr}$ during Campaign 8 and permitted measurements of zirconium DFs without the use of tracers. Although the radiation doses from these fuels were significantly higher than before (because of the higher burnups and shorter cooling times), the operation of the mixer-settlers was not noticeably different from the Campaign 7 behavior. Also, no significant problems with respect to phase separation, formation of solids, or gassing were observed. However, the length of each run was relatively short $(\sim 14 \mathrm{~h})$; 
ORNL DWG 84-11633-R1

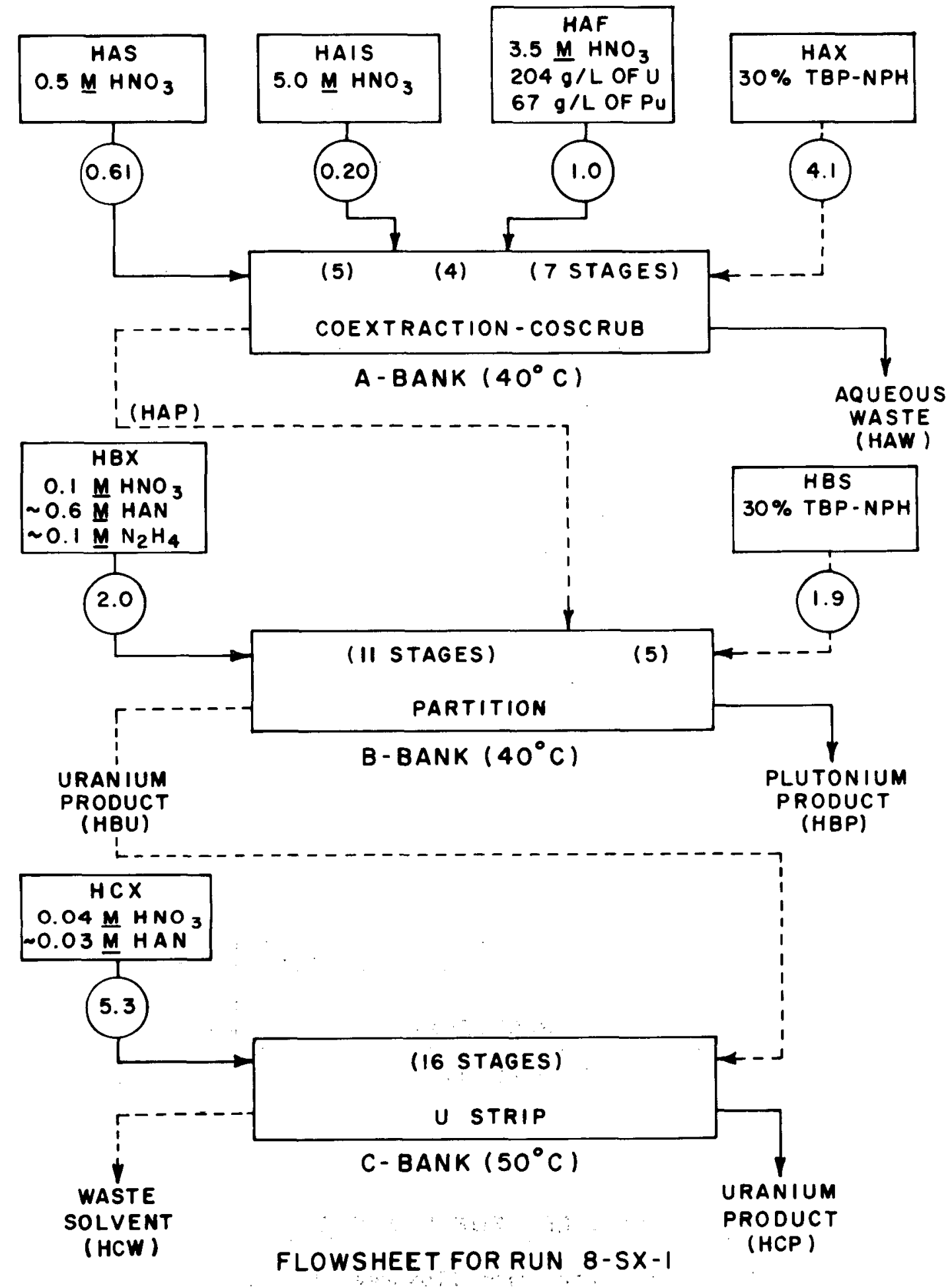

Fig. 2. FFTF solvent extraction flowsheet for Run 8-1, using the organic backscrub method for partitioning. 
ORNL DWG 84-11632-R4

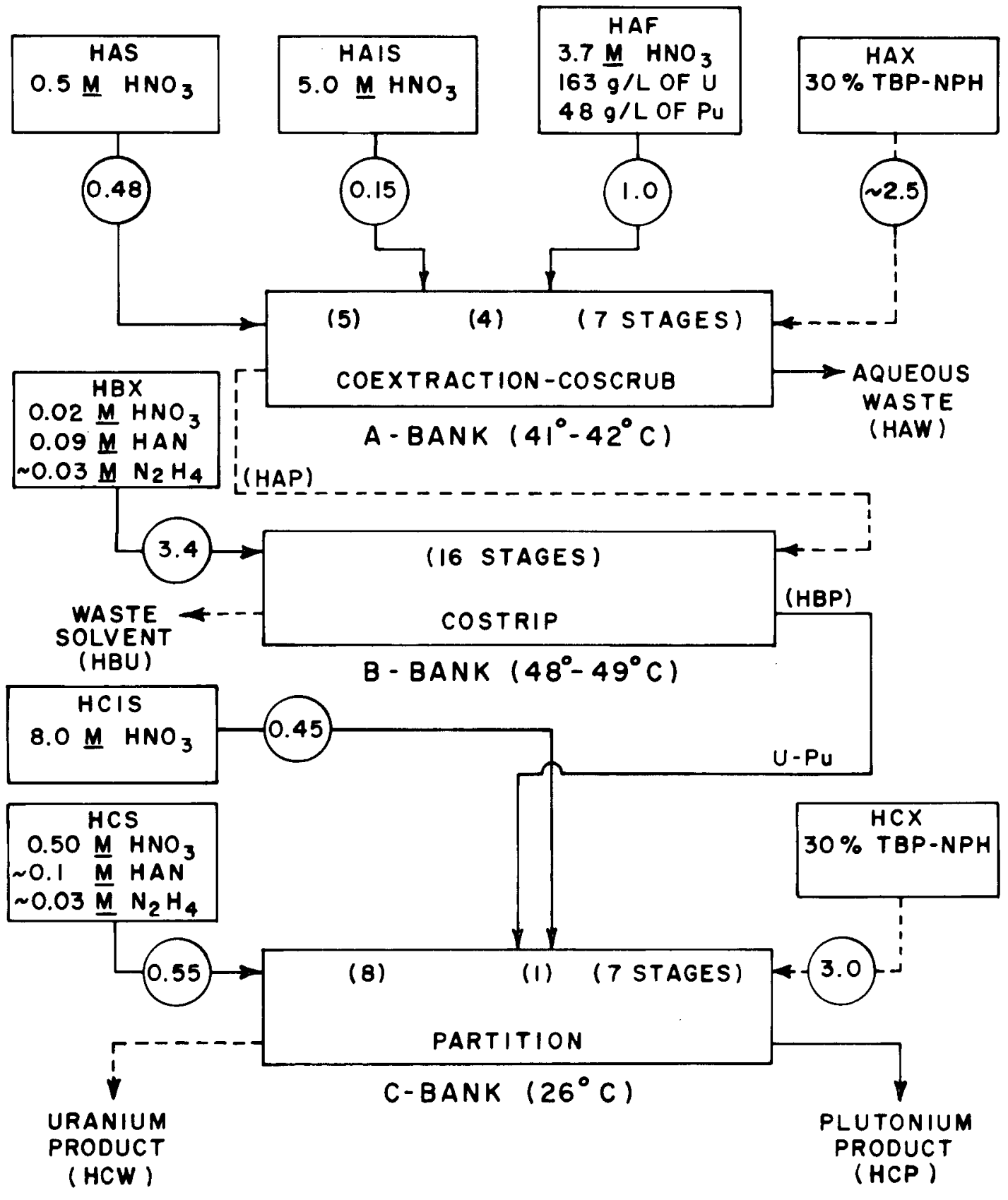

FLOWSHEET FOR RUN $8-5 X-3$

Fig. 3. FFTF solvent extraction flowsheet for Run 8-3, using the selective uranium extraction method for partitioning. 
Table 1. Fission product activity concentrations in the feed solutions during Campaigns 7 and 8

\begin{tabular}{lcrr}
\hline \multirow{2}{*}{ Radionuclide } & \multicolumn{3}{c}{ Activity $[\mathrm{GBq} /(\mathrm{kg} \mathrm{U}+\mathrm{Pu})]$} \\
\cline { 2 - 4 } & Runs $7-1$ and $7-2^{\mathrm{a}}$ & Run $8-1^{\mathrm{b}}$ & Run $8-3^{\mathrm{c}}$ \\
\hline${ }^{5} \mathrm{Zr}$ & 2 & 550 & 3,050 \\
$9{ }^{5} \mathrm{Nb}$ & 3 & 601 & 2,090 \\
$10{ }^{3} \mathrm{Ru}$ & & & 30 \\
$10{ }^{6} \mathrm{Ru}$ & 180 & 1,300 & 1,870 \\
$1{ }^{34} \mathrm{Cs}$ & & & 1,320 \\
$1{ }^{37} \mathrm{Cs}$ & 160 & 2,400 & 5,030 \\
$1{ }^{4} \mathrm{Ce}$ & & & 52 \\
$14{ }^{4} \mathrm{Ce}$ & 480 & 12,400 & 31,200 \\
$154 \mathrm{Eu}$ & 0.7 & 34 & 150 \\
$155_{\mathrm{Eu}}$ & & 390 & 1,010 \\
\hline
\end{tabular}

$\mathrm{a}_{\mathrm{DEA}-1}$ fue1; 2.2-MWd/kg burnup, cooled $\sim 2$ years.

$\mathrm{b}_{\mathrm{DE}-1-6}$ fuel; $\sim 36-\mathrm{MWd} / \mathrm{kg}$ burnup, cooled $\sim 1.3$ years.

$\mathrm{C}_{\mathrm{DE}-2-1 \mathrm{R}}$ fuel; $\sim 55-\mathrm{MWd} / \mathrm{kg}$ burnup, cooled $\sim 1$ year.

therefore, any effect requiring a longer initiation period would not have been detected.

\subsection{RESULTS FROM THE COEXTRACTION-COSCRUBBING CONTACTOR}

Two flowsheet changes were made in Campaign 8 in an attempt to improve fission product DFs. First, the number of scrub stages was increased (with a corresponding decrease in the extraction stages); and second, the heavy-metal loading in the solvent was increased (in Run 8-3 only). The arrangement of the low-acid scrub/high-acid scrub/extraction stages changed from $3 / 3 / 10$ and $4 / 4 / 8$ for Runs $7-1$ and $7-2$, respectively, to $5 / 4 / 7$ for both Runs 8-1 and 8-3. The peak saturation of the solvent was increased from $\sim 50 \%$ for Run 8-1 to $-90 \%$ for Run $8-3$ (peak saturation in Campalgn 7 was 
-60 to $65 \%)$. With each change in the scrub/extraction stages and with the increase in the solvent loading, the DFs for ${ }^{95} \mathrm{Zr}$ and ${ }^{106} \mathrm{Ru}$ steadily increased while losses of uranium and plutonium to the aqueous waste stream (HAW) were maintained at acceptably low levels (Table 2).

Figure 4 presents concentration profiles for zirconium and ruthenium in both the aqueous and the organic phases. The large difference in the solvent loadings for Runs $8-1$ and $8-3$ is shown in Fig. 5. The effect of loading on ${ }^{95} \mathrm{Zr}$ and ${ }^{106} \mathrm{Ru}$ is well illustrated in Fig. 6, which provides a comparison of the organic-phase concentration profiles for ${ }^{95} \mathrm{Zr}$ and ${ }^{106} \mathrm{Ru}$. Near the feed stage (stage 10), where the solvent loading was the highest, the concentrations of ${ }^{95} \mathrm{Zr}$ and ${ }^{106} \mathrm{Ru}$ were decreased by factors of $\sim 100$ in Run 8-3 in spite of the higher-activity feed (Table 1). However, there is less difference between the two profiles near the ends of the contactor.

Table 2. Uranium and plutonium losses and fission product decontamination results in coextraction-coscrubbing

\begin{tabular}{|c|c|c|c|c|}
\hline & \multicolumn{4}{|c|}{ Run } \\
\hline & $7-1$ & $7-2$ & $8-1$ & $8-3$ \\
\hline \multicolumn{5}{|c|}{ Extraction losses, \% } \\
\hline Uranium & 0.002 & 0.003 & $<0.001$ & 0.008 \\
\hline Plutonium & 0.011 & 0.012 & 0.02 & 0.02 \\
\hline \multicolumn{5}{|c|}{ Fission product DFs } \\
\hline${ }^{95} \mathrm{Zr}$ & $9 \mathrm{E} 1^{\mathrm{a}}$ & $7 \mathrm{E} 2$ & $5 \mathrm{E} 3$ & $2 \mathrm{E} 4$ \\
\hline $95_{\mathrm{Nb}}$ & $2 \mathrm{E} 2$ & $4 \mathrm{E} 3$ & $9 \mathrm{E} 3$ & $7 \mathrm{E} 3$ \\
\hline $106_{\mathrm{Ru}}$ & $6 \mathrm{E} 2$ & $3 \mathrm{E} 3$ & $7 \mathrm{E} 3$ & $2 \mathrm{E} 4$ \\
\hline${ }^{137} \mathrm{Cs}$ & $>4 \mathrm{E} 5$ & $>7 \mathrm{E} 5$ & $3 \mathrm{E} 5$ & $>6 \mathrm{E} 6$ \\
\hline $141_{\mathrm{Ce}}$ & & & & $2 \mathrm{E} 4$ \\
\hline${ }^{144} \mathrm{Ce}$ & $>1 \mathrm{E} 5$ & $>2 \mathrm{E} 5$ & $>4 \mathrm{E} 5$ & $>7 \mathrm{E} 6$ \\
\hline $15{ }^{4} \mathrm{Eu}$ & $>7 E 4$ & $>1 E 4$ & $>2 \mathrm{E} 3$ & $>3 \mathrm{E} 5$ \\
\hline $155_{\mathrm{Eu}}$ & & & $>2 \mathrm{E} 4$ & $>4 \mathrm{E} 5$ \\
\hline
\end{tabular}

$a_{\text {To be read as }} 9 \times 10^{1}$. 

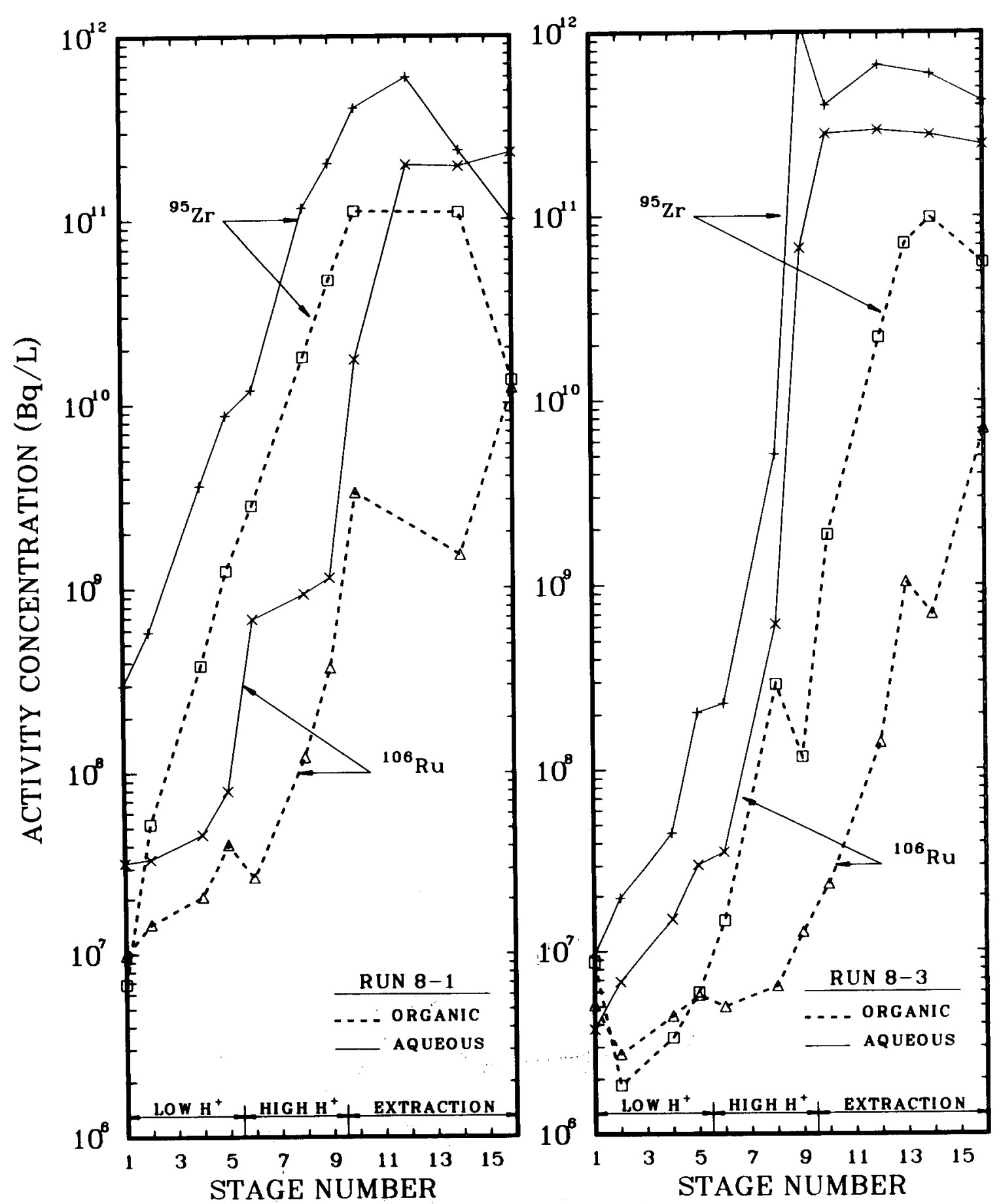

Fig. 4. Concentration profiles for ${ }^{95} \mathrm{Zr}$ and ${ }^{106} \mathrm{Ru}$ in the extractionscrubbing contactor for Runs $8-1$ and $8-3$. 
ORNL DWG-86-115

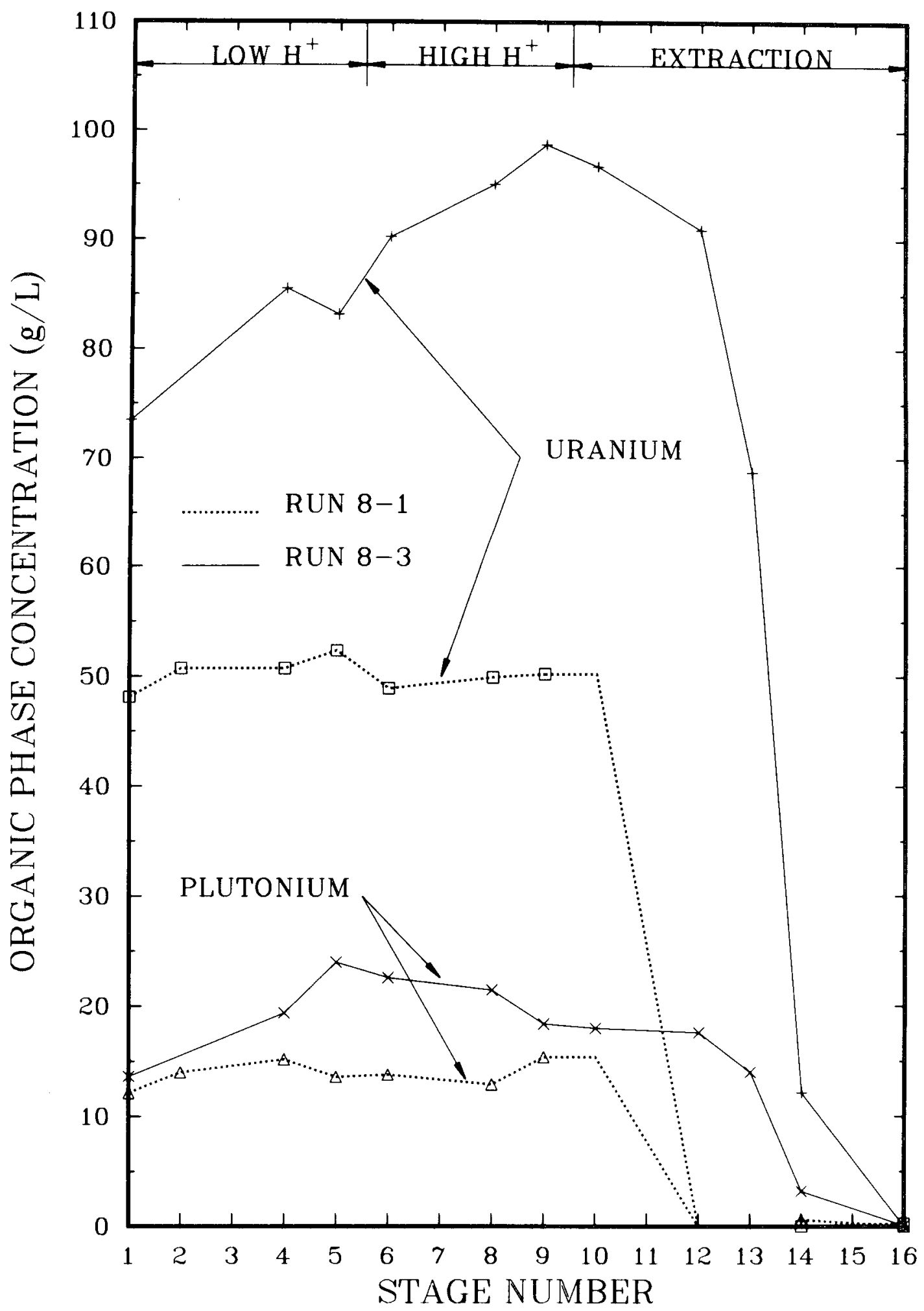

Fig. 5. Organic-phase profiles for uranium and plutonium in the extraction-scrubbing contactor for Runs $8-1$ and 8-3. 
ORNL DWG-86-116
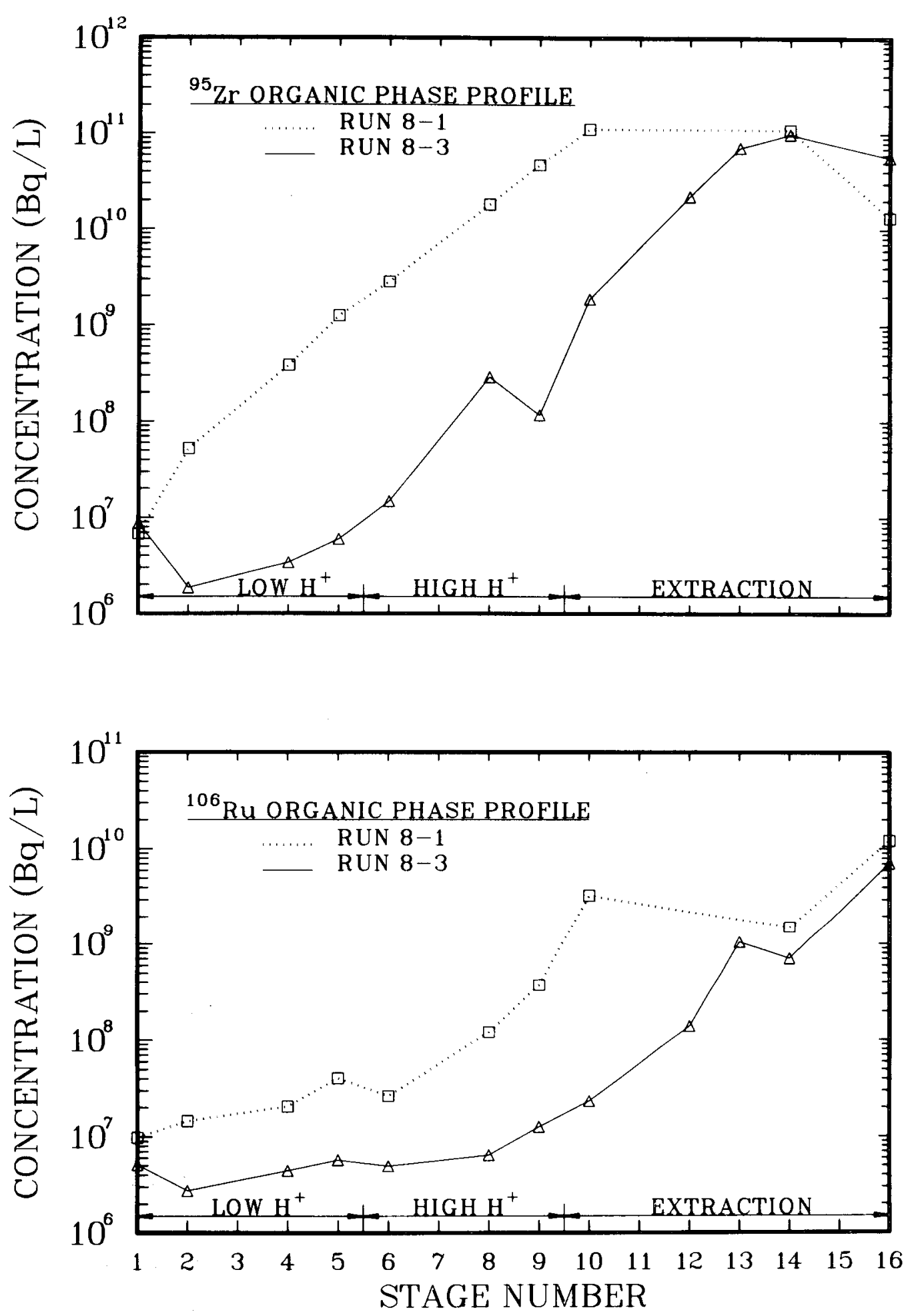

Fig. 6. Organic-phase profiles for ${ }^{95} \mathrm{Zr}$ and ${ }^{106} \mathrm{Ru}$ in Runs $8-1$ and $8-3$. 
At the extraction end, the heavy-metal loading drops in Run 8-3 to maintain low losses of uranium and plutonium to the aqueous waste stream. Because most of the fission products are present in the aqueous raffinate at this end, they are extracted and reach levels similar to those found in Run 8-1. The fission product concentrations in the solvent decreased more rapidly in the scrub section for Run 8-1 than they did in Run 8-3 so that, even though the profiles for Run 8-1 started at higher values, they tend to converge somewhat toward the outlet. These data may indicate that such factors as entrainment, solvent degradation products, or suspended solids may have become significant during Run 8-3.

\subsection{RESULTS FROM THE PARTITIONING AND STRIP CONTACTORS}

\subsubsection{Organic Backscrub}

In Campaign 7, a flowsheet was tested using HAN without hydrazine as the plutonium reductant. Complete recovery of the plutonium was not achieved with a HAN/plutonium mol ratio of 2; however, satisfactory products were obtained in Run $7-3 B$ with a ratio of $\sim 4$. Although good products were obtained during Run 7-3B, plutonfum reoxidation was noticeable in the scrub section of the contactor, as indicated by the relatively high plutonium extraction coefficients $(0.2$ to 0.4$)$ and the generation of more acid than expected on the basis of the reduction reaction stoichiometry.

Hydrazine, which has been commonly used to destroy nitrous acid and thereby help minimize $\mathrm{Pu}$ (III) reoxidation, was included in the Campaign 8 test in an attempt to improve the plutonium stripping behavior; otherwise, the conditions were the same as those used in Run 7-3B. Run 8-1

ylelded satisfactory product solutions (Table 3) similar to the previous run (7-3B); however, the plutonium behavior in the strip section was not significantly different, and the reoxidation of plutonium in the scrub section was st111 noticeable (Fig. 7).

Although the plutonium extraction coefficients in the scrub section in Run 8-1 were lower by factors of 2 to 3 , they were still quite high, ranging from 0.1 to 0.2 . In addition, the $\mathrm{H}^{+}$balance (Table 4) for Run 8-1 was essentially the same as before, $\sim 5$ mol of $\mathrm{H}^{+}$generated per mol of 
ORNL DWG-86-117

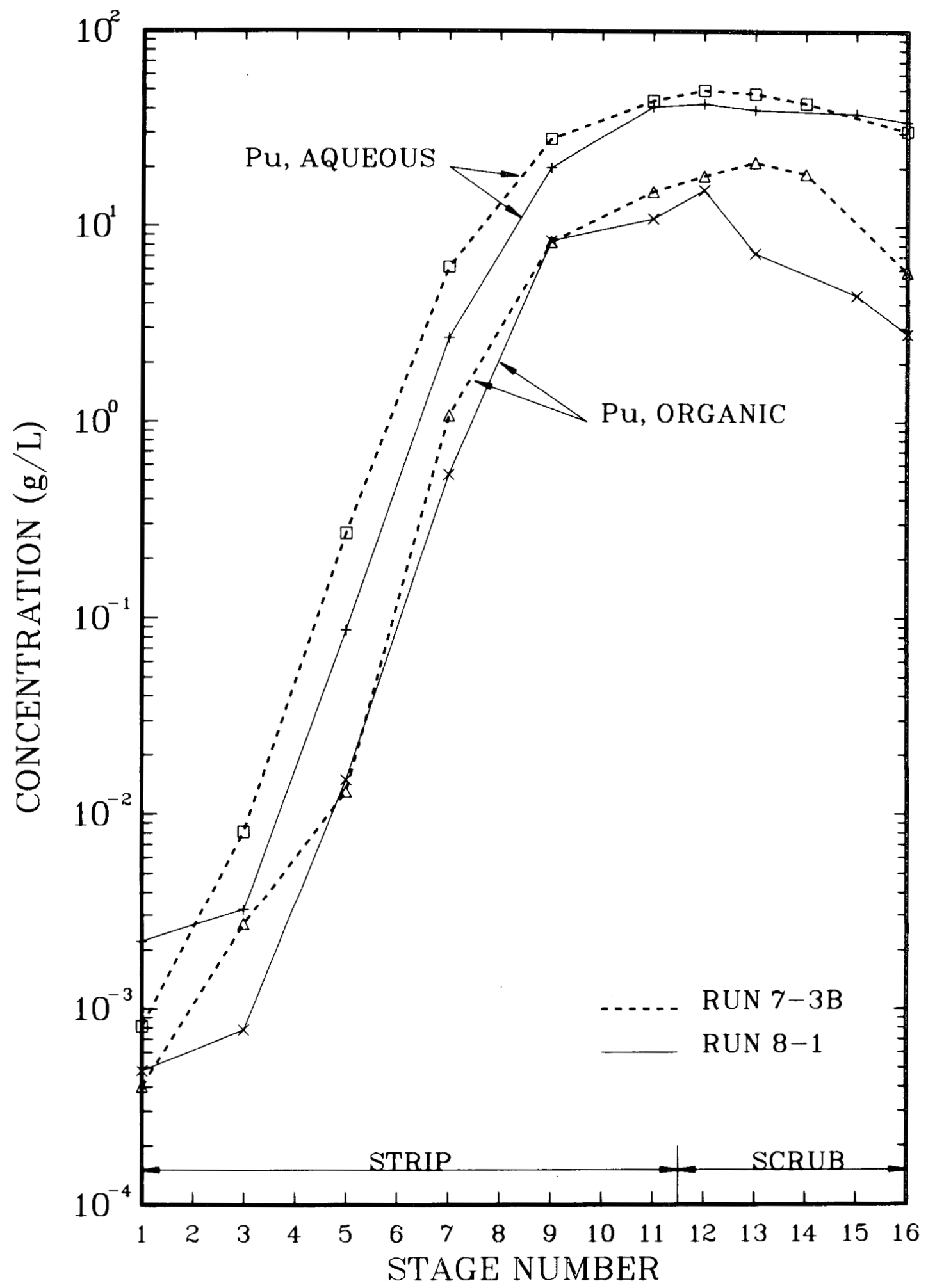

Fig. 7. Concentration profiles of plutonium in the partition contactor for Runs 7-3B and 8-1. 
Table 3. Total partitioning results

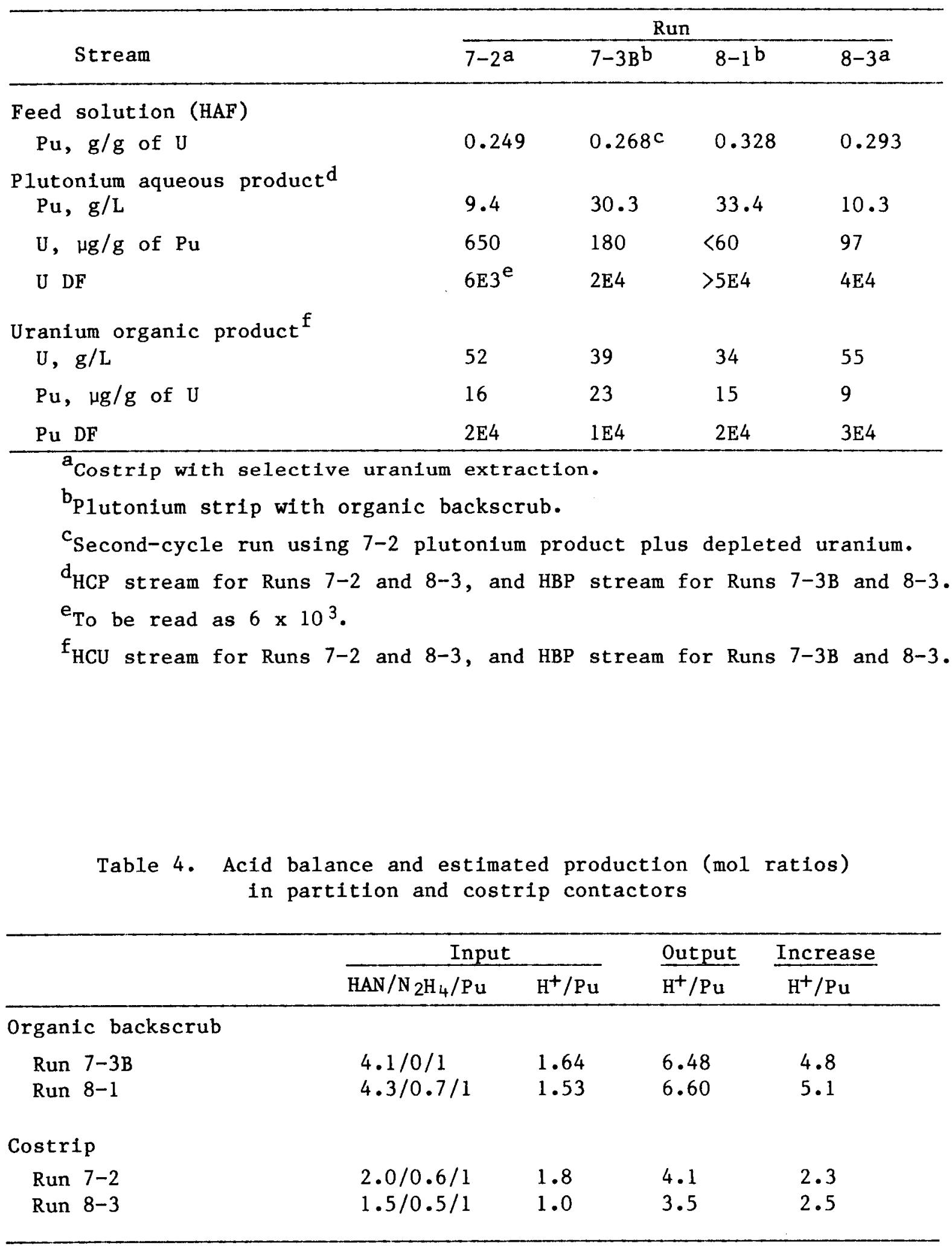


plutonium added to the contactor. This acid production is an indication that the HAN is being consumed by something besides the reaction with the $\mathrm{Pu}(\mathrm{IV})$ present in the feed, since the accepted stoichiometry ${ }^{9}$ has only 2 mol of $\mathrm{H}^{+}$produced per mol of plutonium reduced. Furthermore, the nitrous acid concentration in the organic feed was still low in this run ( $<0.001 \underline{M}$ as before), so the HAN consumption was probably the result of cyclic reduction-reoxidation-reduction reactions that were not significantly stopped by the addition of hydrazine.

Again, the most likely reaction is the reoxidation of $\mathrm{Pu}($ III) in the solvent. 10 Although the quantity of $\mathrm{Pu}$ (III) extracted is quite sma11, the reoxidation reaction is rapid; ${ }^{11}$ and when breeder fuels with high plutonium concentrations are processed, this reaction probably becomes significant. The hydrazine is able to scavenge nitrous acid from the aqueous phase [which probably helps since nitrous acid is a catalyst for $\mathrm{Pu}$ (III) reoxidation], but apparently it is unable to stop the reaction in the organic phase.

The concentration profiles for uranium in the partition contactors for Runs $7-3 B$ and $8-1$ are shown in Fig. 8. The uranium separation from the plutonium product is slightly better (Table 3 ) in Run $8-1$; of course, this result may be a consequence of the slightly lower plutonium concentrations in the solvent for the scrub section as shown in Fig. 7 .

\subsubsection{Selective Uranium Extraction}

The partitioning conditions used in Run 8-3 were essentially the same as those used earlier in Run 7-2, and similar products were obtained (Table 3). As shown in Figs. 9 through 11; the concentration profiles for the two runs are stmilar except for plutonium in the partition contactor (Fig, 10).

The reoxidation problem that was noticed in the organic backscrub flowsheet (Sect. 4.2.1) was not observed in the costrip contactor because of the very low acid concentrations present in this contactor $(0.02$ to $0.2 \mathrm{M} \mathrm{H}^{+}$in the aqueous; see ref. 5 for a profile of aqueous-phase acidity measured in Campaign 7). The acid balance shows only $\sim 2.4$ mol of $\mathrm{H}^{+}$ 
ORNL DWG-86-118

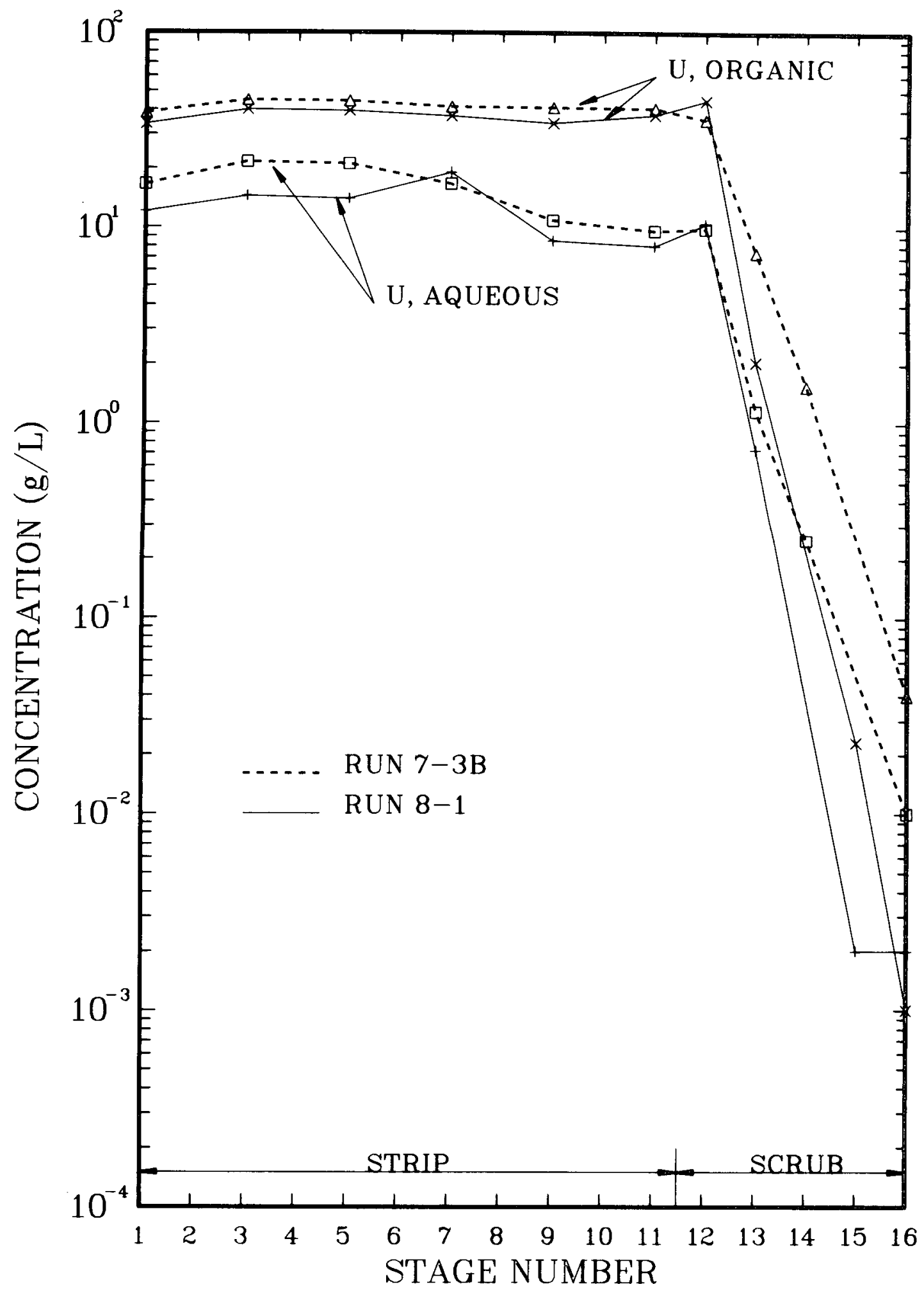

Fig. 8. Concentration profiles of uranium in the partition contactor for Runs $7-3 B$ and $8-1$. 
ORNL DWG-86-119

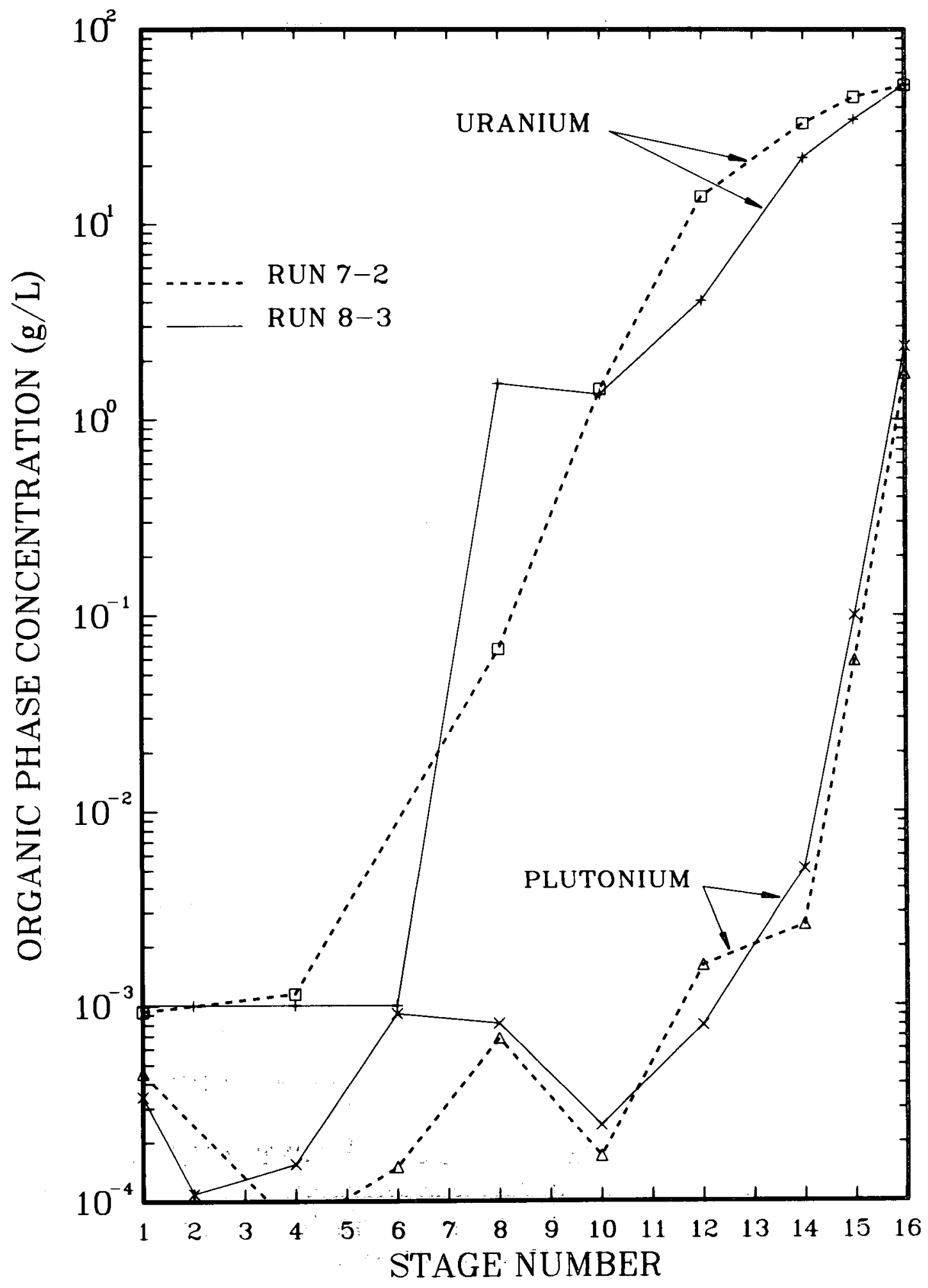

Fig. 9. Concentration profiles of plutonium and uranium in the costrip contactor for Runs 7-2 and 8-3. 
ORNL DWG-86-120

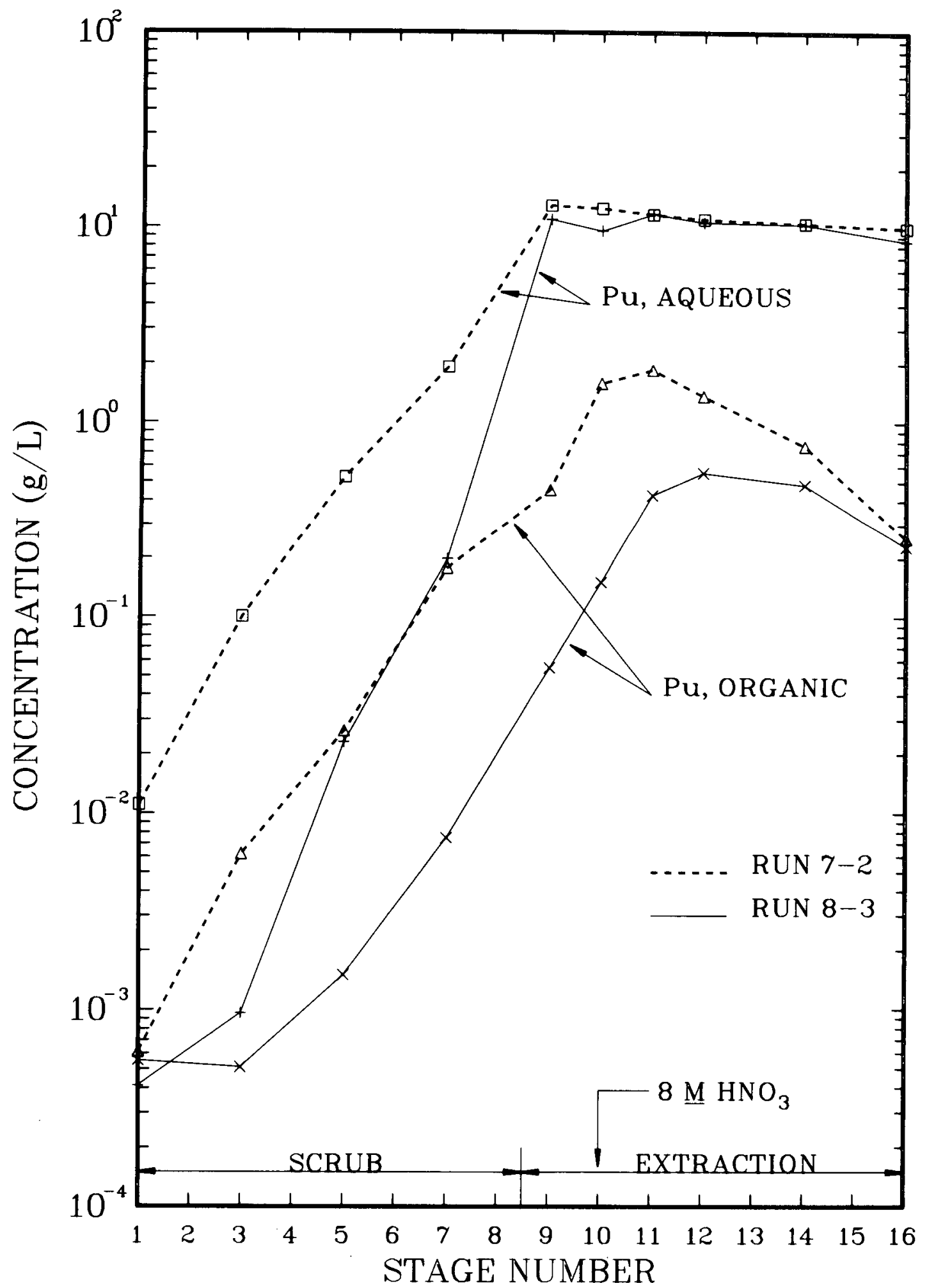

Fig. 10. Concentration profiles of plutonium in the partition contactor for Runs 7-2 and 8-3. 
ORNL DWG-86-121

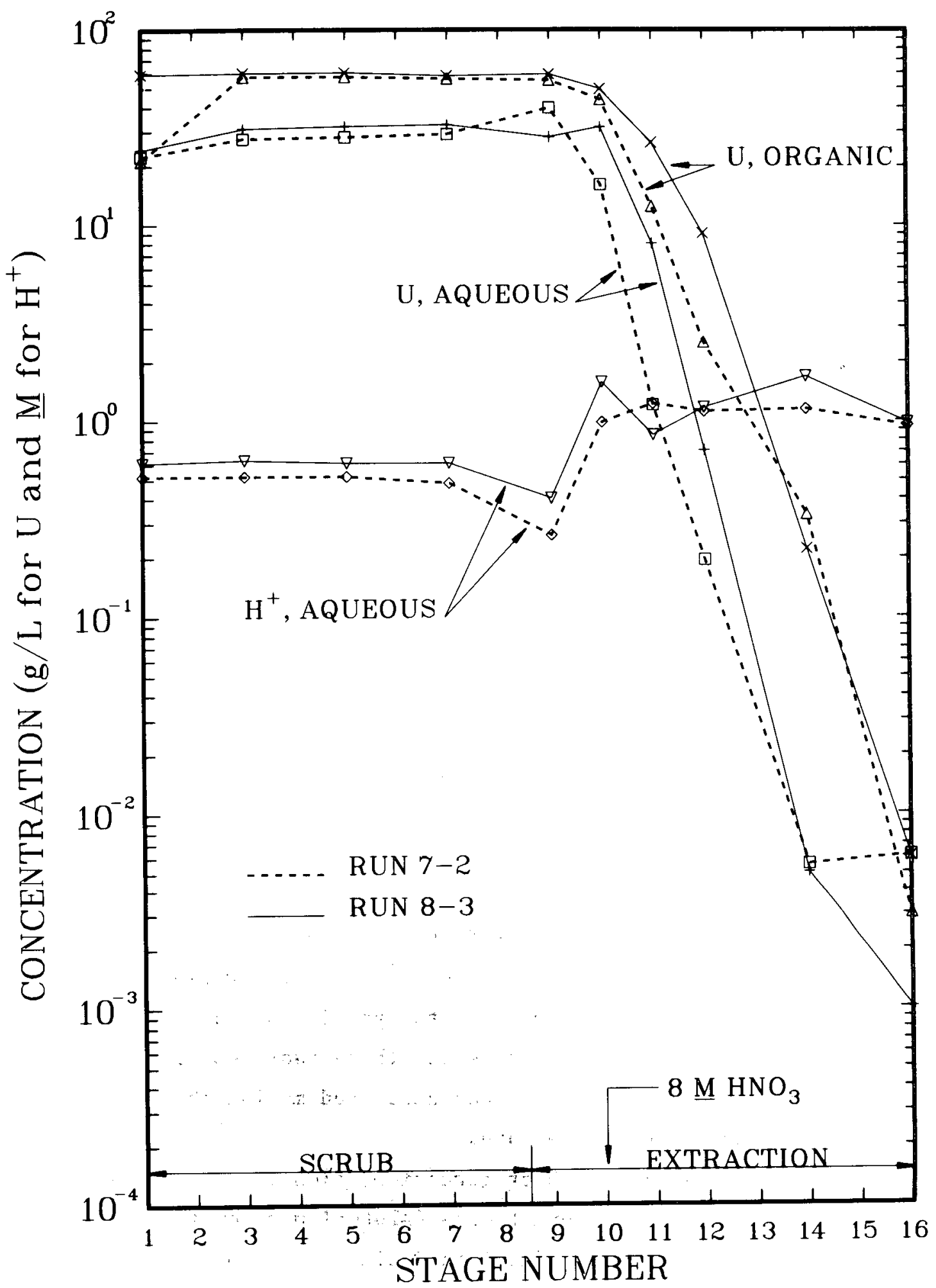

Fig. 11. Concentration profiles of uranium and nitric acid in the partition bank for Runs 7-2 and 8-3. 
produced per mol of plutonium stripped (Table 4), which is close to the accepted stoichiometry of 2. The plutonium concentration in the solvent was lowered to $<1 \mathrm{mg} / \mathrm{L}$ in only six stages as a result of the low acidity, the rapid reduction with $\mathrm{HAN}$, and the lack of any significant reoxidation. The uranium did not strip as quickly as the plutonium, which is normal for a costrip flowsheet, because the aqueous acidities were relatively high for uranium stripping in order to minimize plutonium hydrolysis. Also, uranium stripping was hindered by the $0.1 \mathrm{M} H A N$, which was added to the strip solution for plutonium reduction and acts as an inextractable salt. However, the flowsheet was run with a sufficiently high strip flow rate to decrease the uranium concentration in the organic phase to $<1 \mathrm{mg} / \mathrm{L}$ in 12 stages (10 stages for Run 8-3).

Although the same flowsheet conditions were used in Runs 7-2 and 8-3, a comparison of plutonium profiles (Fig. 10) shows some unexpected differences. The aqueous concentrations in the extraction section show good agreement and the shapes of the two organic profiles are simflar, with a slight peak in the extraction section (which suggests that some plutonium reflux is occurring), but the organic-phase concentrations are significantly lower for Run 8-3. The reason for this difference is not known; however, it is possible that the plutonium was refluxing but had not reached steady-state concentrations when these profile samples were taken.

\subsubsection{Zirconium and Ruthenium}

Because of the higher burnup and shorter cooling times of the fuel used in Campaign 8 , the ${ }^{95} \mathrm{Zr}$, ${ }^{95} \mathrm{Nb}$, and ${ }^{106} \mathrm{Ru}$ concentrations could be detected and measured in streams from the partition and strip contactors.

Unfortunately, the material balances for these 1sotopes were poor, ranging from 70 to $600 \%$ recovery across a contactor and making the calculated DFs for individual contactors uncertain.

The relative distributions of zirconium, niobium, and ruthenium that were found in the three outlet streams (plutonium product, uranium product, and waste solvent) are listed in Table 5. The overall DFs for uranium and plutonium as calculated from the final product streams are also 
Table 5. Percentages of ${ }^{95} \mathrm{Zr},{ }^{95} \mathrm{Nb}$, and ${ }^{106} \mathrm{Ru}$ in the outlet streams from the strip and partition contactors, and the overall DFs for the final plutonium and uranium products

\begin{tabular}{|c|c|c|c|c|c|c|}
\hline \multirow[b]{2}{*}{ Stream } & \multicolumn{3}{|c|}{ Run 8-1 } & \multicolumn{3}{|c|}{ Run $8-3$} \\
\hline & $95 \mathrm{Zr}$ & $95 \mathrm{Nb}$ & ${ }^{106_{\mathrm{Ru}}}$ & $\overline{95} \mathrm{Zr}$ & $95 \mathrm{Nb}$ & ${ }^{106} \mathrm{Ru}$ \\
\hline $\mathrm{Pu}$ product (aqueous) ${ }^{\mathbf{a}}$ & 96.6 & 39.8 & 15.8 & 57.3 & 51.1 & 16.2 \\
\hline $\mathrm{U}$ product (aqueous) ${ }^{\mathrm{b}}$ & 0.8 & 21.0 & 6.8 & & & \\
\hline $\mathrm{U}$ product (organic) ${ }^{\mathrm{C}}$ & & & & 0.4 & 0.07 & 1.0 \\
\hline Waste solvent ${ }^{d}$ & 2.6 & 39.2 & 77.4 & 42.4 & 48.8 & 82.8 \\
\hline Overall DF for $\mathrm{Pu}$ product & $2 \mathrm{E} 3$ & $1 \mathrm{E} 4$ & $2 \mathrm{E} 4$ & $4 \mathrm{E} 4$ & $9 E 3$ & $9 \mathrm{E} 4$ \\
\hline Overall DF for $U$ product ${ }^{f}$ & $2 \mathrm{E} 5$ & $2 \mathrm{E} 4$ & $5 E 4$ & $6 \mathrm{E} 6$ & $7 \mathrm{E} 6$ & $2 \mathrm{E} 6$ \\
\hline
\end{tabular}

$a_{\text {HBP }}$ stream from partition bank for Run 8-1; HCP stream from partition bank for Run 8-3.

$b_{\text {HCP }}$ stream from uranium strip bank for Run 8-1.

HCW stream from partition bank for Run 8-3.

$d_{\text {HCW }}$ stream from uranium strip bank for Run $8-1$; HBU stream from costrip bank for Run 8-3.

${ }^{e}$ Calculated from the aqueous feed (HAF) and plutonium product from the partition bank.

${ }^{\mathrm{C}} \mathrm{Calculated}$ from the aqueous feed (HAF) and the uranium product (HCP streams for Run 8-1 and the HCW stream for Run 8-3.

included. Note that the uranfum product in Run 8-3 is listed as the organic stream from the partition contactor; to strip this uranium would have required a fourth contactor that was not available in the SETF. Therefore, the uranium DFs would probably be somewhat higher than those shown if the uranium stripping had been included.

In each run, more ${ }^{95} \mathrm{Zr}, 95 \mathrm{Nb}$, and ${ }^{106} \mathrm{Ru}$ were found in the plutonium than in the uranium products. As a result the overall DFs for the uranium products were higher than those for plutonium. The bulk of the zirconium was measured in the plutonium product in Run 8-1, but it was divided about evenly between the plutonium and the waste solvent in Run 8-3. Approximately equal amounts of niobium were found in the outlet streams, except 
for the Run 8-3 uranium product (organic phase), which contained very ifttle activity. The bulk of the ruthenfum was never stripped and remained in waste solvents, although a smaller but significant amount of ruthenium did appear to strip with each plutonium product.

\subsection{RESULTS FROM THE IN-LINE PHOTOMETER}

The in-line photometer (Fig. 1) system was operated during two mixersettler runs. The first, Run 8-2, used depleted uranium as feed to provide a simple test of the system; the second, Run 8-3, was made with irradiated fuel. In each run, organic solvent was pumped from Stage 13 settler through the knockout pot, the sample cell, and back to the Stage 12 mixer (solvent flows from stage 16 to stage 1 in the coextraction-coscrub contactor). The flow rate through the sample loop was set to $\sim 0.5 \mathrm{~L} / \mathrm{h}$, which was $\sim 50$ and $60 \%$ of the total solvent flow in Runs 8-2 and 8-3, respectively.

The first run with depleted uranium was plagued with significant emulsion problems that were apparently caused by impurities in the uranium feed. Fortunately, the knockout pot in the sample loop successfully removed the aqueous phase from the emulsion; and, In spite of these problems, the photometer system still worked in a reasonable manner giving consistent readings and responding to changes in the extraction bank conditions. The only significant anomaly occurred at high uranium loadings $(>60 \mathrm{~g} / \mathrm{L})$, where the photometer reading tended to spike off scale. This action may have been caused by excessive absorption of the light signal through the sample cel1, which can be corrected by simply changing the length of the light path. In any case, it was not a serious concern since these uranium concentrations were well above our desired control point.

Based on the photometer reading of the uranium concentration, adjustments in the solvent addition rate were made in an attempt to control the uranium loading. Although the photometer readings varied (Fig. 12), the uranium concentrations in samples of (1) the organic product, (2) the feed stage solvent, and ( 3 ) the aqueous raffinate were fairly constant ( $\sim 85$, 
ORNL DWG-86-122

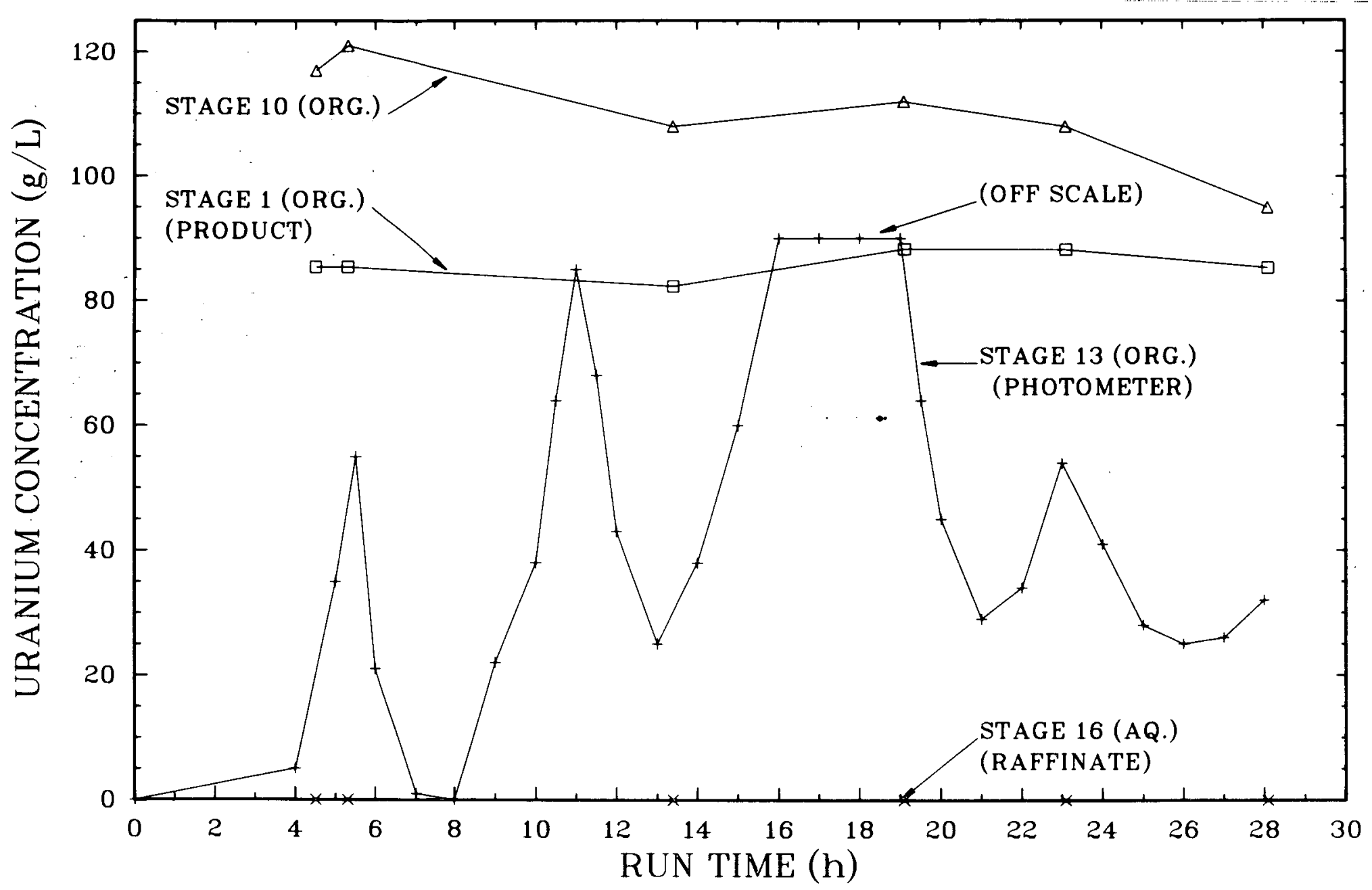

Fig. 12. Sample results and photometer readings from Run 8-2. 
$\sim 110$, and $\sim 0.002 \mathrm{~g} / \mathrm{L}$, respectively). During the run, samples were also withdrawn from the Stage 13 solvent in order to estimate the accuracy of the instrument (Table 6 ). The ratio of the photometer reading to the analyzed uranium concentration averaged 0.87 , with a standard deviation of $14 \%$.

After the uranium run, the photometer system was recalibrated for solutions containing both uranium and plutonium and then used in a test with irradiated fuel (Run 8-3). During this test, the photometer system measured both uranium and plutonium concentrations in the solvent at the same point as before, Stage 13 in the extraction section. Once more, we tried to control the heavy-metal loading in the extraction bank by making small adjustments in the addition rate of the solvent to the contactor in order to keep the photometer readings near a desired value. Although these readings varied, the alpha monitor in the product stream from the extraction bank (HAP) showed only a slight variation (Fig. 13) and losses to the aqueous raffinate were kept low (Table 2). During this run, samples were again taken from the Stage 13 solvent. The ratio of the photometer readings to the solution analyses averaged 0.98 , with a standard deviation of $11 \%$, for uranium; they averaged 0.87 with a standard deviation of $30 \%$, for plutonium.

\section{PLUTONIUM PURIFICATION AND CONVERSION TO OXIDE}

Each of the aqueous plutonium product solutions recovered from the solvent extraction processing (Runs 8-1 and 8-3) was purified by one cycle of anion exchange; the product recoveries were 97 and $99 \%$, respectively. The purified solutions were then converted to the oxide form by batch precipitation of plutonium oxalate followed by calcination to $\mathrm{PuO}_{2}$. Two oxalate precipitation procedures were used (Sect. 2.2 and ref. 3). The plutonium from Run 8-1 was precipitated as Pu(III) oxalate, while that from Run 8-3 was precipitated as $\mathrm{Pu}(\mathrm{IV})$ oxalate; the product recovery was $-94 \%$ in each case. No significant problems were noted with either procedure, although the filtrates from the $\mathrm{Pu}$ (III) step required special processing to remove HAN before being concentrated by boiling. 
Table 6. Comparison of the photometer readings with solution sample analyses

\begin{tabular}{|c|c|c|c|c|c|c|}
\hline \multirow[b]{2}{*}{$\begin{array}{l}\text { Time } \\
(\mathrm{h})\end{array}$} & \multicolumn{3}{|c|}{ Uranium $(\mathrm{g} / \mathrm{L})$} & \multicolumn{3}{|c|}{ Plutonium (g/L) } \\
\hline & $\begin{array}{l}\text { Photometer } \\
\text { reading }\end{array}$ & $\begin{array}{l}\text { Solution } \\
\text { analysis }\end{array}$ & Rat1o ${ }^{a}$ & $\begin{array}{l}\text { Photometer } \\
\text { reading }\end{array}$ & $\begin{array}{l}\text { Solution } \\
\text { analysis }\end{array}$ & Ratioa \\
\hline \multicolumn{7}{|c|}{ Run 8-2 } \\
\hline 5 & 20.4 & 23.7 & 0.86 & & & \\
\hline 6 & 54.6 & 53.7 & 1.02 & & & \\
\hline 14 & 28.7 & 35.0 & 0.82 & & & \\
\hline 20 & 46.7 & 46.3 & 1.01 & & & \\
\hline 24 & 41.0 & 57.8 & 0.71 & & & \\
\hline 29 & 34.5 & 41.9 & $\underline{0.82}$ & & & \\
\hline \multicolumn{3}{|c|}{ Average } & 0.87 & & & \\
\hline \multicolumn{3}{|c|}{ Standard deviation } & $14 \%$ & & & \\
\hline
\end{tabular}

Run 8-3

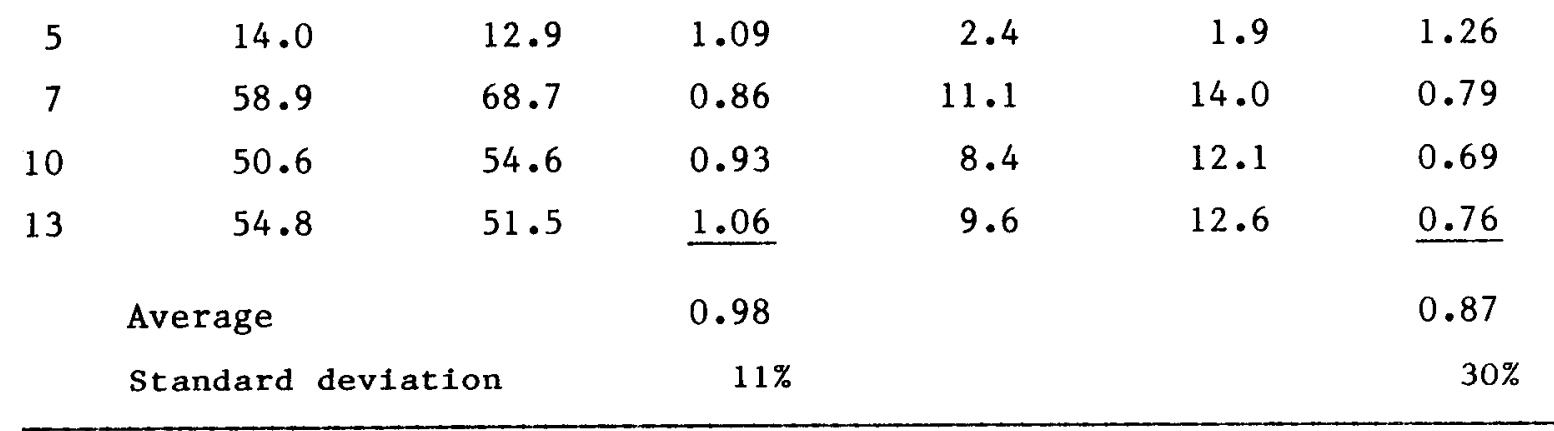

${ }^{a}$ Photometer readings divided by the solution analyses. 
ORNL DWG-86-123
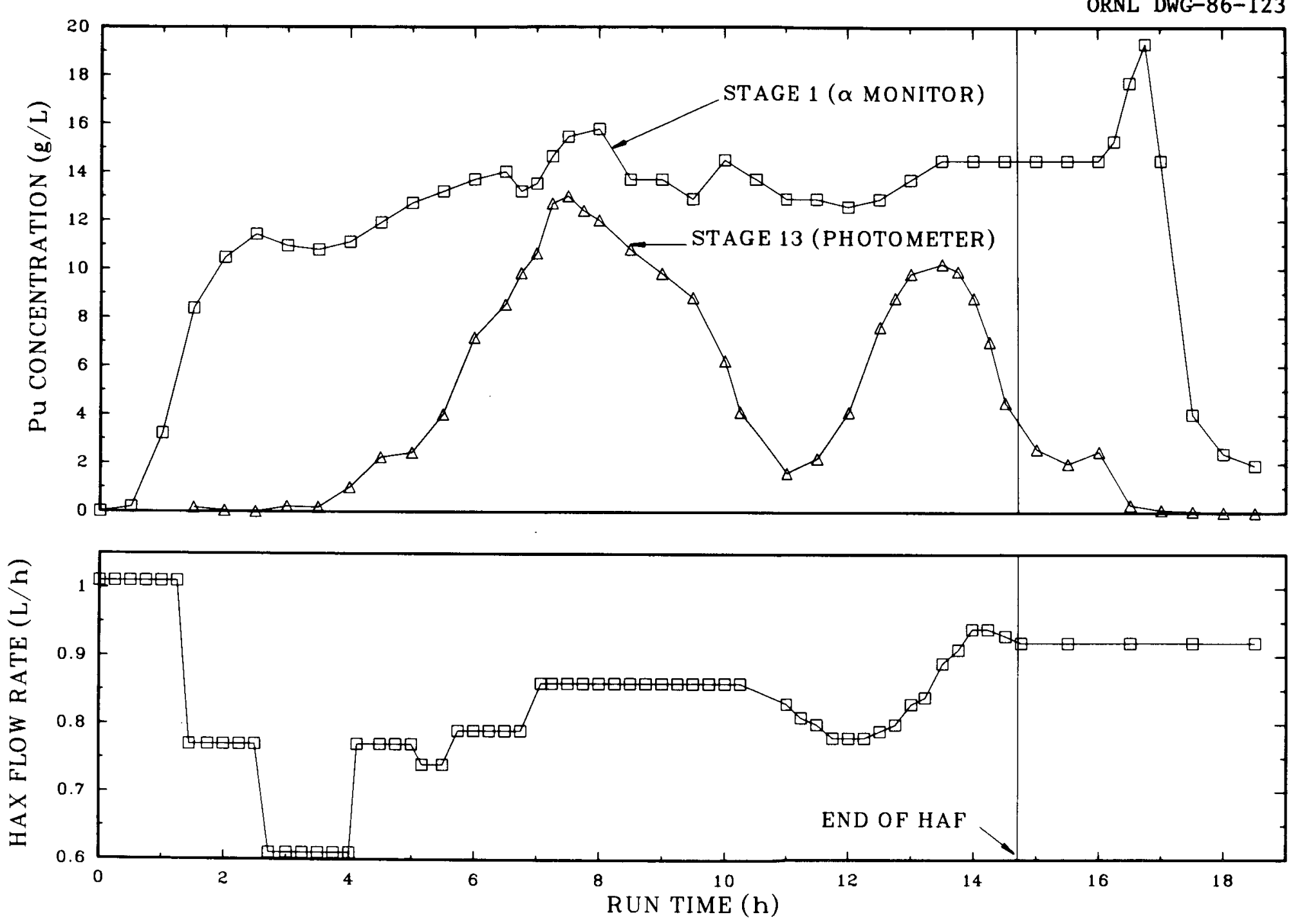

Fig. 13. Concentration readings from the coextraction-coscrub bank in Run 8-3, using the in-line alpha monitor and the in-line photometer. 
Table 7 lists the radioactivity levels of some of the fission product radionuclides in the final plutonium oxide products and the overall DF values achleved by the combined processing steps - solvent extraction, anion exchange, and oxalate precipitation. The only measurable gammaemitting fission products left in the oxide products, ${ }^{95} \mathrm{Zr}$ and ${ }^{106} \mathrm{Ru}$, were present in satisfactorily low concentrations. The higher $\mathrm{DF}$ for ${ }^{95} \mathrm{Zr}$ in the second batch is the result of the the better DF achieved in the solvent extraction step (Run 8-3); the DFs for anton exchange and oxalate precipitation were about the same for each batch. The oxide products contained a total of $450 \mathrm{~g}$ of plutonium, which represents $\sim 85 \%$ of the plutonium originally measured in the dissolver solutions. These products have been packaged and sent to HEDL.

Table 7. Radioactivity levels of fission product radionuclides in plutonium oxide products, and the overall DF values achieved

\begin{tabular}{|c|c|c|c|c|}
\hline \multirow{2}{*}{$\begin{array}{l}\text { Fission } \\
\text { product } \\
\text { radionuclide }\end{array}$} & \multicolumn{2}{|c|}{$\begin{array}{l}\text { Radioactivity leve1 } \\
\text { in product }(\mathrm{MBq} / \mathrm{kg} \mathrm{Pu})\end{array}$} & \multicolumn{2}{|c|}{ Overall $\mathrm{DF}^{\mathrm{a}}$} \\
\hline & Batch $1^{b}$ & Batch $2 \mathrm{c}$ & Batch 1 & Batch 2 \\
\hline $95 \mathrm{Zr}$ & 160 & 72 & $1 E 4^{d}$ & $2 \mathrm{E} 5$ \\
\hline $106_{\mathrm{Ru}}$ & 9 & $<20$ & $6 \mathrm{E} 5$ & $>5 \mathrm{E} 5$ \\
\hline${ }^{137} \mathrm{Cs}$ & $<1$ & $<\dot{2}$ & $>9 \mathrm{E} 6$ & $>1 \mathrm{E} 7$ \\
\hline${ }^{144} \mathrm{Ce}$ & $<9$ & $<6$ & $>6 \mathrm{E} 6$ & $>2 \mathrm{E} 7$ \\
\hline${ }^{15{ }^{4} \mathrm{Eu}}$ & $<3$ & $<2$ & $>4 \mathrm{E} 4$ & $>4 \mathrm{E} 5$ \\
\hline \multicolumn{5}{|c|}{ 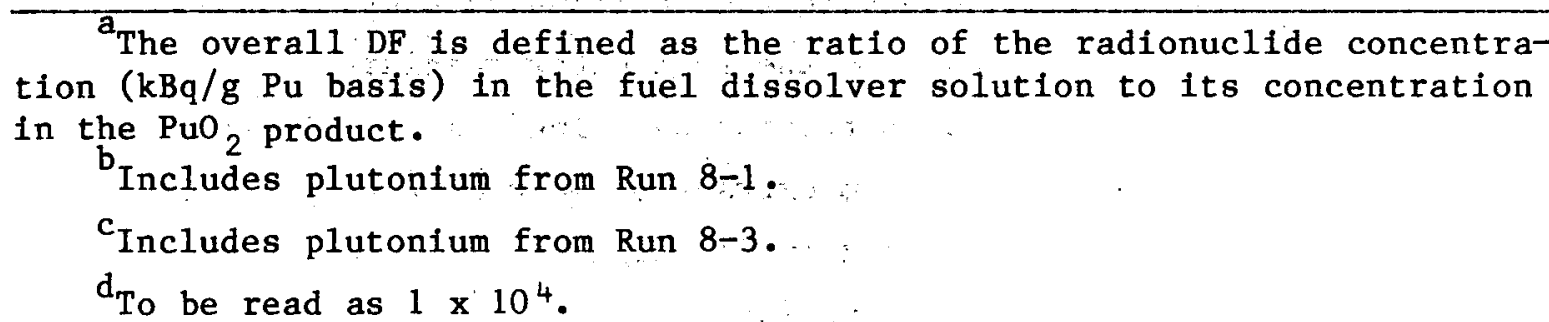 } \\
\hline
\end{tabular}




\section{SUMMARY AND CONCLUSIONS}

The more significant results and conclusions regarding the solvent extraction flowsheet and the in-line photometer tests conducted with irradiated FFTF fuel are as follows:

1. The use of higher-burnup and shorter-cooled fuel in this campaign did not adversely affect the operation of the mixer-settlers. The physical operation of the contactors was good with regard to both phase separation and solid accumulations and was not noticeably different from previous campaign operations with low-burnup fuel. However, the duration of each test was relatively short $(\sim 14 \mathrm{~h})$; hence, any problems that require a long time to develop would not have been detected in our tests.

2. The coextraction-coscrub bank operated successfully and yielded low losses of uranium and plutonium. The DFs for zirconium and ruthenium were improved by increasing the peak solvent loading from $\sim 50 \%$ to $\sim 90 \%$. At the higher saturation, the removal of the fission products in the scrub section was less efficient; this fact may suggest that the scrubbing efficiencies could have been affected by factors such as entrainment, solvent degradation products, or suspended solids.

3. An in-line photometer system for measuring uranium and plutonium concentrations in process streams was installed and tested. In this campaign, the instrument measured the heavy-metal concentrations in the organic phase of the coextraction bank. A high solvent loading of heavy metals ( $~ 90 \%$ peak saturation) was achieved while maintaining low losses to the aqueous raffinate (HAW) by making small adjustments in the addition rate of the organic extractant (HAX) based on the photometer readings.

4. Uranium and plutonium partitioning using the organic backscrub and the selective uranium extraction methods both yielded products as good as those obtained in Campaign 7 . The addition of hydrazine to the strip solution for the organic backscrub flowsheet did not significantly reduce the plutonium reoxidation problem that was first noted in Campaign 7. 
5. The $\mathrm{Pu}(\mathrm{III})$ and $\mathrm{Pu}(\mathrm{IV})$ oxalate precipitation procedures yielded the same product recovery, $\sim 94 \%$. However, the $\mathrm{Pu}$ (III) procedure was more troublesome in that the raffinate streams from this procedure contain $\mathrm{HAN}$ and $\mathrm{HNO}_{3}$ and must be handled more carefully. Approximately $85 \%$ of the plutonium recovered from the dissolution of the FFTF fuel was successfully purified and converted to an oxide product. The oxide, which contained $450 \mathrm{~g}$ of plutonium, has been sent to HEDL for refabrication studies.

\section{ACKNOWLEDGMENTS}

The experimental work done in the SETF was performed by the Chemical Technology Division staff of the Transuranium Processing Plant. The extensive analytical work was carried out by Analytical Chemistry Division personnel, primarily under the supervision of J. L. Botts, J. M. Peele, and D. A. Costanzo. Engineering and maintenance services were provided by personnel from the General Engineering Division, the Instrumentation and Controls Division, and Plant Equipment Division, under the supervision of S. 0. Lewis, E. M. Shuford and B. R. Scarborough. Also, invaluable assistance was given by D. D. McCue in the installation and startup of the in-1ine photometer and by $D$. J. Crouse in the selection of flowsheet conditions and the control algorithm for the microcomputer. 


\section{REFERENCES}

1. E. D. Collins, D. E. Benker, J. E. Bigelow, F. R. Chattin, M. H. Lloyd, L. J. King, R. G. Ross, and H. C. Savage, Solvent Extraction Studies of Coprocessing Flowsheets - Results from Campaigns 1 and 2 of the Solvent Extraction Test Facility (SETF), ORNL/TM-7080, Oak Ridge National Laboratory, Ju1y 1982 .

2. E. D. Collins, D. E. Benker, J. E. Bigelow, F. R. Chattin, L. J. King, R. G. Ross, and H. C. Savage, Solvent Extraction Studies of Coprocessing Flowsheets - Results from Campaigns 3 and 4 of the Solvent Extraction Test Fac1lity (SETF), ORNL/TM-7991, Oak Ridge National Laboratory, May 1982 .

3. W. D. Bond, D. E. Benker, J. E. Bigelow, F. R. Chattin, E. D. Collins, L. J. King, R. G. Ross, and H. C. Savage, Solvent Extraction Studies of Coprocessing Flowsheets - Results from Campaign 5 of the Solvent Extraction Test Facility (SETF), ORNL/TM-8598, Oak Ridge National Laboratory, November 1983.

4. D. E. Benker, J. E. Bigelow, E. D. Collins, F. R. Chattin, L. J. King, H. C. Savage, R. G. Ross, and R. G. Stacy, Solvent Extraction Studies of Coprocessing Flowsheets - Results from Campaign 6 of the Solvent Extraction Test Facility (SETF), ORNL/TM-9961, Oak Ridge National Laboratory (in press).

5. D. E. Benker, J. E. Bigelow, W. D. Bond, F. R. Chattin, L. J. King, F. G. Kitts, R. G. Ross, and R. G. Stacy, Solvent Extraction Studies with Low Burnup Fast Flux Test Facility Fuel in the Solvent Extraction Test Facility, ORNL/TM-9189, Oak Ridge National Laboratory, January 1985 .

6. D. T. Bostick and J. E. Strain, Experimental Parameters in the Photometric Analysis of Uranium in TBP-Dodecane Solutions, ORNL/TM-7551, Oak Ridge National Laboratory, January 1981 .

7. D. T. Bostick and J. E. Strain, Photometric Determination of Plutonium in Organic Purex Solutions, ORNL/TM-8286, Oak Ridge National Laboratory, March 1983.

8. K. M. Harmon and W. H. Reas, Conversion Chemistry of Plutonium Nitrate, HW-49597A, Apri1 1957.

9. G. S. Barney, "A Kinetic Study of the Reaction of Plutonium(IV) with Hydroxylamine," J. Inorg. Nucl. Chem. 38, 1677-81 (1975).

10. Yu-Keung Sze, L. J. Clegg, A. F. Gerwing, and G. R. Grant, "Oxidation of $\mathrm{Pu}(\mathrm{III})$ by Nitric Acid in Tri-n-Butyl Phosphate Solutions. Part I. Kinetics of the Reaction and Its Effect on Plutonium Losses in Countercurrent Liquid-Liquid Extraction," Nuc1. Technol. 56, 527-34 (March 1982). 


\section{$35 / 36$}

11. V. V. Revyakin, V. I. Marchenko, E. S. Gitovich, N. A. Korableva, and V. P. Varykhanov, "Oxidation Kinetics of Plutonium(III) by Nitrous Acid in a Tributy1 Phosphate Solution," Sov. Radiochem. 25, 317-21 (May-June 1983). 
APPENDIX A

Table A-1. Campaign 8 - fuel pin identification numbers

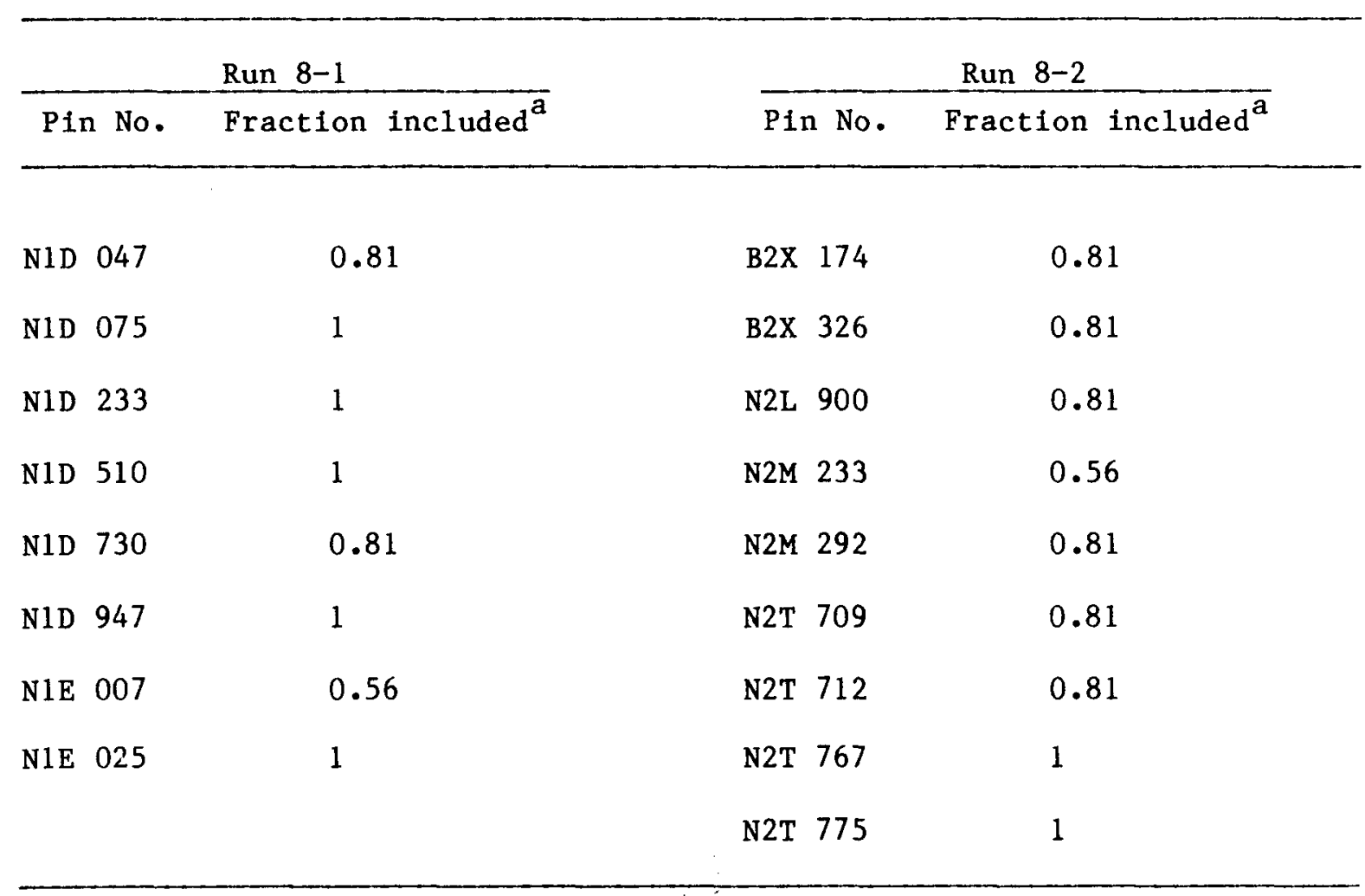

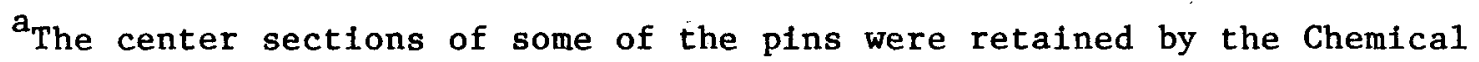
Development Section for fuel characterization studies. 
Table A-2. Campaign 8 first-cycle tests - extraction scrub bank conditions and results

\begin{tabular}{|c|c|c|c|}
\hline & \multicolumn{3}{|c|}{ Run No. } \\
\hline & $8-1$ & $8-2$ & $8-3$ \\
\hline Dates & $3 / 21-22 / 84$ & $5 / 2-3 / 84$ & $5 / 16-17 / 84$ \\
\hline Bank temperature, ${ }^{\circ} \mathrm{C}$ & 40 & $40-41$ & $41-42$ \\
\hline \multicolumn{4}{|l|}{ Number of stages } \\
\hline $\begin{array}{l}\text { Final scrub/ } \\
\text { inter. scrub/extraction }\end{array}$ & $5 / 4 / 7$ & $5 / 4 / 7$ & $5 / 4 / 7$ \\
\hline HAX stream flow rate, $L / h$ & 1.00 & $1.0^{a}$ & $0.8^{b}$ \\
\hline \multicolumn{4}{|l|}{ Flow ratios } \\
\hline $\mathrm{HAS} / \mathrm{HAX}$ & 0.149 & 0.15 & 0.192 \\
\hline HAIS/HAX & 0.049 & 0.043 & 0.061 \\
\hline HAF / HAX & 0.244 & 0.35 & 0.402 \\
\hline \multicolumn{4}{|l|}{ In1et stream compositions } \\
\hline HAS stream, $\mathrm{HNO}_{3}, \mathrm{~mol} / \mathrm{L}$ & 0.49 & 0.50 & 0.50 \\
\hline $\begin{array}{l}\text { HAIS stream, } \mathrm{HNO}_{3}, \mathrm{~mol} / \mathrm{L} \\
\mathrm{HAX} \text { stream, \% TBP } \\
\text { HAF stream }\end{array}$ & $\begin{array}{l}5.0 \\
30.0 \pm 0.5\end{array}$ & $\begin{array}{l}5.0 \\
30.0 \pm 0.5\end{array}$ & $\begin{array}{l}5.0 \\
30.0 \pm 0.5\end{array}$ \\
\hline $\mathrm{HNO}_{3}, \mathrm{~mol} / \mathrm{L}$ & $\begin{array}{l}3.5 \\
204\end{array}$ & $\begin{array}{l}4.1 \\
264\end{array}$ & $\begin{array}{l}3.7 \\
163\end{array}$ \\
\hline $\begin{array}{l}\mathrm{Pu}, \mathrm{g} / \mathrm{L} \\
233_{\mathrm{Np}}, \mathrm{mg} / \mathrm{L}\end{array}$ & 67.0 & & $\begin{array}{l}48.0 \\
56\end{array}$ \\
\hline $24 \mathrm{l}_{\mathrm{Am}}, \mathrm{g} / \mathrm{L}$ & 0.47 & & 0.25 \\
\hline $242 \mathrm{Cm}, \mathrm{mg} / \mathrm{L}$ & 1.75 & & 3.7 \\
\hline $95 \mathrm{Zr}, \mathrm{GBq} / \mathrm{L}$ & 150 & & 645 \\
\hline $95 \mathrm{Nb}, \mathrm{GBq} / \mathrm{L}$ & 163 & & 442 \\
\hline $103_{\mathrm{Ru}}, \mathrm{GBq} / \mathrm{L}$ & & & 6.4 \\
\hline $106 \mathrm{Ru}, \mathrm{GBq} / \mathrm{L}$ & 360 & & 397 \\
\hline $125 \mathrm{Sb}, \mathrm{GBq} / \mathrm{L}$ & $<20$ & & $<40$ \\
\hline $134 \mathrm{Cs}, \mathrm{GBq} / \mathrm{L}$ & & & 279 \\
\hline $137 \mathrm{Cs}, \mathrm{GBq} / \mathrm{L}$ & 640 & & 1070 \\
\hline${ }^{141} \mathrm{Ce}, \mathrm{GBq} / \mathrm{L}$ & & & 11 \\
\hline $1{ }^{44} \mathrm{Ce}, \mathrm{GBq} / \mathrm{L}$ & 3370 & & 6600 \\
\hline${ }^{154} \mathrm{Eu}, \mathrm{GBq} / \mathrm{L}$ & 9.2 & & 32 \\
\hline $155_{\mathrm{Eu}}, \mathrm{GBq} / \mathrm{L}$ & 106 & & 215 \\
\hline
\end{tabular}


Table A-2 (continued)

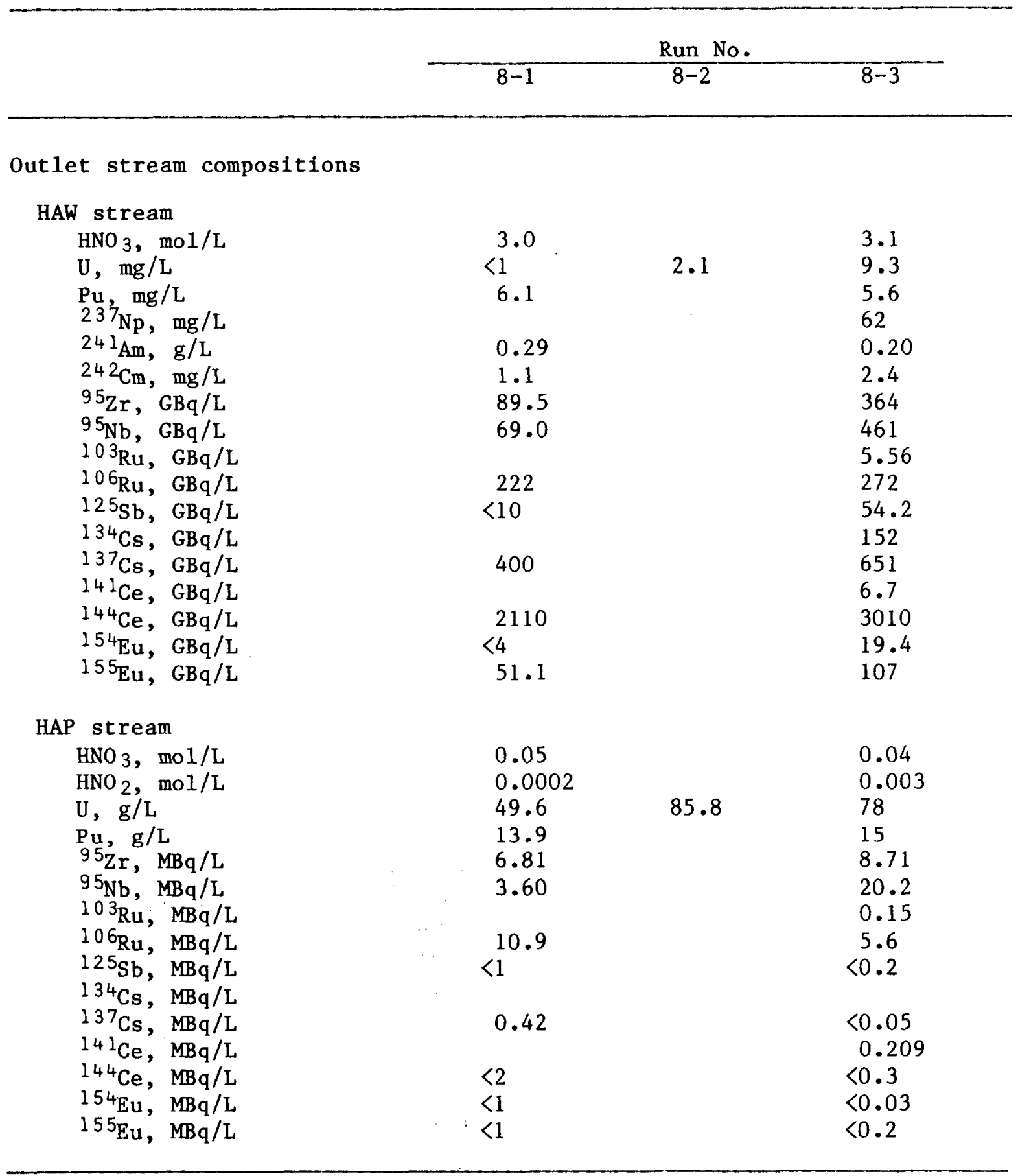

${ }^{a}$ Average flow rate; the $\mathrm{HAX}$ varied from 0.9 to $1.2 \mathrm{~L} / \mathrm{h}$ during the run. ${ }^{b}$ Average flow rate; the HAX varied from 0.6 to $0.96 \mathrm{~L} / \mathrm{h}$ during the run. 
Table A-3. Campaign 8 first-cycle tests - conditions and results for B-bank contactor

\begin{tabular}{|c|c|c|}
\hline & \multicolumn{2}{|c|}{ Run No. } \\
\hline & $8-1^{a}$ & $8-3^{b}$ \\
\hline Dates & $3 / 21-22 / 84$ & $5 / 16-17 / 84$ \\
\hline Bank temperature, ${ }^{\circ} \mathrm{C}$ & 40 & $48-49$ \\
\hline \multicolumn{3}{|l|}{ Number of stages } \\
\hline Strip/scrub & $11 / 5$ & $16 / 0$ \\
\hline HBX stream flow rate, $L / h$ & 0.483 & 1.097 \\
\hline \multicolumn{3}{|l|}{ F1ow ratios } \\
\hline $\mathrm{HAP} / \mathrm{HBX}$ & 2.07 & $0.7^{c}$ \\
\hline HBS/HBX & 0.97 & \\
\hline \multicolumn{3}{|l|}{ Inlet stream compositions } \\
\hline \multicolumn{3}{|l|}{ HBX stream } \\
\hline $\mathrm{HNO}_{3}, \mathrm{~mol} / \mathrm{L}$ & 0.1 & 0.02 \\
\hline $\mathrm{HAN}, \mathrm{d} \mathrm{mol} / \mathrm{L}$ & 0.6 & 0.09 \\
\hline $\mathrm{N}_{2} \mathrm{H}_{4}, \mathrm{~mol} / \mathrm{L}$ & 0.1 & 0.03 \\
\hline HBS stream, \% TBP & $30.0 \pm 0.5$ & \\
\hline \multicolumn{3}{|l|}{ HAP stream } \\
\hline $\mathrm{HNO}_{3}, \mathrm{~mol} / \mathrm{L}$ & 0.05 & 0.04 \\
\hline $\mathrm{HNO}_{2}, \mathrm{~mol} / \mathrm{L}$ & 0.0002 & 0.003 \\
\hline $\mathrm{U}, \mathrm{g} / \mathrm{L}$ & 49.6 & 78 \\
\hline $\mathrm{Pu}, \mathrm{g} / \mathrm{L}$ & 13.9 & 15 \\
\hline $95 \mathrm{Zr}, \mathrm{GBq} / \mathrm{L}$ & 6.81 & 8.71 \\
\hline $95 \mathrm{Nb}, \mathrm{GBq} / \mathrm{L}$ & 3.60 & 20.2 \\
\hline $103_{\mathrm{Ru}}, \mathrm{GBq} / \mathrm{L}$ & & 0.15 \\
\hline $106 \mathrm{Ru}, \mathrm{GBq} / \mathrm{L}$ & 10.9 & 5.6 \\
\hline $125 \mathrm{Sb}, \mathrm{GBq} / \mathrm{L}$ & $<1$ & $<0.2$ \\
\hline $134 \mathrm{Cs}, \mathrm{GBq} / \mathrm{L}$ & & \\
\hline $137 \mathrm{Cs}, \mathrm{GBq} / \mathrm{L}$ & 0.42 & $<0.05$ \\
\hline $141_{\mathrm{Ce}}, \mathrm{GBq} / \mathrm{L}$ & & 0.209 \\
\hline $144 \mathrm{Ce}, \mathrm{GBq} / \mathrm{L}$ & $<2$ & $<0.3$ \\
\hline $154 \mathrm{Eu}, \mathrm{GBq} / \mathrm{L}$ & $<1$ & $<0.03$ \\
\hline $255_{\mathrm{Eu}}, \mathrm{GBq} / \mathrm{L}$ & $<1$ & $<0.2$ \\
\hline
\end{tabular}


Table A-3 (continued)

\begin{tabular}{|c|c|c|}
\hline & \multicolumn{2}{|c|}{ Run No. } \\
\hline & $8-1^{a}$ & $8-3 b$ \\
\hline Outlet stream comp & & \\
\hline $\begin{array}{l}\mathrm{HBP} \text { stream } \\
\text { HNO } 3, \mathrm{mo} 1 / \mathrm{L} \\
\mathrm{U}, \mathrm{g} / \mathrm{L} \\
\mathrm{Pu}^{2}, \mathrm{~g} / \mathrm{L} \\
23^{\mathrm{Np}} \mathrm{mg} / \mathrm{L} \\
95_{\mathrm{Zr}}, \mathrm{MBq} / \mathrm{L} \\
95_{\mathrm{Nb}} \mathrm{MBq} / \mathrm{L} \\
103 \mathrm{Ru}, \mathrm{MBq} / \mathrm{L} \\
106_{\mathrm{Ru}} \mathrm{MBq} / \mathrm{L} \\
125 \mathrm{Sb}, \mathrm{MBq} / \mathrm{L} \\
134 \mathrm{Cs}, \mathrm{MBq} / \mathrm{L} \\
137 \mathrm{Cs}, \mathrm{MBq} / \mathrm{L} \\
1{ }^{1} \mathrm{Ce}, \mathrm{MBq} / \mathrm{L} \\
144_{\mathrm{Ce}} \mathrm{MBq} / \mathrm{L} \\
154 \mathrm{Eu}, \mathrm{MBq} / \mathrm{L} \\
155_{\mathrm{Eu}} \mathrm{MBq} / \mathrm{L}\end{array}$ & $\begin{array}{l}1.0 \\
<0.002 \\
33.4 \\
40.1 \\
6.51 \\
8.91 \\
<2\end{array}$ & $\begin{array}{l}0.2 \\
59 \\
12 \\
<0.2 \\
0.82 \\
12 \\
<0.03 \\
0.72 \\
<0.08 \\
\\
<0.03 \\
0.15 \\
0.60 \\
<0.03 \\
0.08\end{array}$ \\
\hline $\begin{array}{l}\text { HBU stream } \\
\mathrm{HNO}_{2}, \mathrm{mo} 1 / \mathrm{L} \\
\mathrm{HNO}_{3}, \mathrm{mo} 1 / \mathrm{L} \\
\mathrm{U}, \mathrm{g} / \mathrm{L} \\
\mathrm{Pu}, \mathrm{mg} / \mathrm{L} \\
95_{\mathrm{Zr}} \mathrm{MBq} / \mathrm{L} \\
95_{\mathrm{Nb}} \mathrm{MBq} / \mathrm{L} \\
103_{\mathrm{Ru}, \mathrm{MBq} / \mathrm{L}} \\
106 \mathrm{Ru}, \mathrm{MBq} / \mathrm{L} \\
125 \mathrm{Sb}, \mathrm{MBq} / \mathrm{L} \\
13{ }^{4} \mathrm{Cs}, \mathrm{MBq} / \mathrm{L} \\
137_{\mathrm{Cs}} \mathrm{MBq} / \mathrm{L} \\
141_{\mathrm{Cs}} \mathrm{MBq} / \mathrm{L} \\
144_{\mathrm{Ce}} \mathrm{MBq} / \mathrm{L} \\
154 \mathrm{Eu}, \mathrm{MBq} / \mathrm{L} \\
155_{\mathrm{Eu}} \mathrm{MBq} / \mathrm{L}\end{array}$ & $\begin{array}{c}0.03 \\
33.8 \\
0.50 \\
0.69 \\
2.7 \\
13.3 \\
<0.08 \\
<0.02 \\
<0.5 \\
<0.02 \\
<0.07\end{array}$ & $\begin{array}{l}0.0003 \\
<0.01 \\
<0.001 \\
0.3 \\
4.93 \\
18.7 \\
0.18 \\
8.22 \\
<0.1 \\
<0.06 \\
\\
<0.2 \\
<0.03 \\
<0.06\end{array}$ \\
\hline
\end{tabular}

$a_{B-b a n k}$ was used as a partitioning contactor.

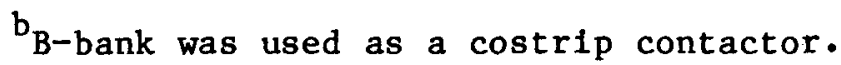

${ }^{\mathrm{C}}$ Average ratio; the HAP flow rate varied from 0.6 to 0.96 during this run.

$\mathrm{d}_{\text {Hydroxylamine nitrate. }}$ 
Table A-4. Uranium strip bank conditions and results for Run 8-1

\begin{tabular}{|c|c|}
\hline & $\begin{array}{c}\text { Run No. } \\
8-1\end{array}$ \\
\hline Dates & $3 / 21-22 / 84$ \\
\hline Bank temperature, ${ }^{\circ} \mathrm{C}$ & 50 \\
\hline \multicolumn{2}{|l|}{ Number of stages } \\
\hline Strip & 16 \\
\hline HCX stream flow rate, $L / h$ & 1.30 \\
\hline \multicolumn{2}{|l|}{ Flow ratios } \\
\hline $\mathrm{HBU} / \mathrm{HCX}$ & 1.13 \\
\hline \multicolumn{2}{|l|}{ Inlet stream compositions } \\
\hline \multicolumn{2}{|l|}{ HCX stream } \\
\hline $\mathrm{HNO}_{3}, \mathrm{~mol} / \mathrm{L}$ & 0.04 \\
\hline HAN, mol/L & 0.03 \\
\hline \multicolumn{2}{|l|}{ HBU stream } \\
\hline $\mathrm{HNO}_{3}, \mathrm{~mol} / \mathrm{L}$ & 0.03 \\
\hline $\mathrm{U}, \mathrm{g} / \mathrm{L}$ & 33.8 \\
\hline $\mathrm{Pu}, \mathrm{mg} / \mathrm{L}$ & 0.050 \\
\hline $95 \mathrm{Zr}, \mathrm{MBq} / \mathrm{L}$ & 0.69 \\
\hline $95 \mathrm{Nb}, \mathrm{MBq} / \mathrm{L}$ & 2.7 \\
\hline $103 \mathrm{Ru}, \mathrm{MBq} / \mathrm{L}$ & \\
\hline $106_{\mathrm{Ru}}, \mathrm{MBq} / \mathrm{L}$ & 13.3 \\
\hline $125 \mathrm{Sb}, \mathrm{MBq} / \mathrm{L}$ & $<0.08$ \\
\hline $134 \mathrm{Cs}, \mathrm{MBq} / \mathrm{L}$ & \\
\hline $137 \mathrm{Cs}, \mathrm{MBq} / \mathrm{L}$ & $<0.02$ \\
\hline $141 \mathrm{Ce}, \mathrm{MBq} / \mathrm{L}$ & \\
\hline${ }^{144} \mathrm{Ce}, \mathrm{MBq} / \mathrm{L}$ & $<0.5$ \\
\hline $154 \mathrm{Eu}, \mathrm{MBq} / \mathrm{L}$ & $<0.02$ \\
\hline $155 \mathrm{Eu}, \quad \mathrm{MBq} / \mathrm{L}$ & $<0.07$ \\
\hline
\end{tabular}


Table A-4 (continued)

\begin{tabular}{|c|c|}
\hline & $\begin{array}{c}\text { Run No. } \\
8-1\end{array}$ \\
\hline Outlet stream comp & \\
\hline 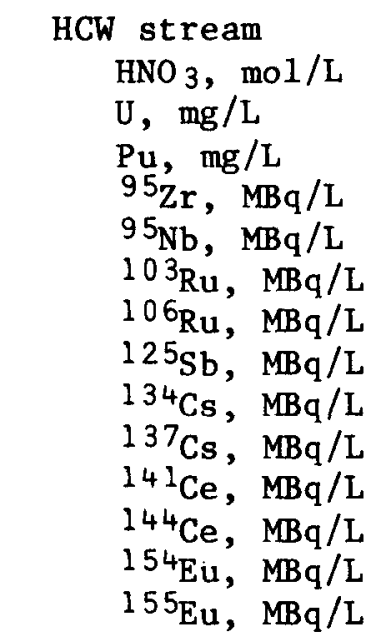 & $\begin{array}{l}0.01 \\
<1 \\
0.044 \\
0.359 \\
2.11 \\
14.3 \\
<0.06 \\
<0.01 \\
\\
0.14 \\
<0.02 \\
<0.02\end{array}$ \\
\hline $\begin{array}{l}\text { HCP stream } \\
\text { HNO } 3, \mathrm{mo} 1 / \mathrm{L} \\
\mathrm{U}, \mathrm{g} / \mathrm{L} \\
\mathrm{Pu}, \mathrm{mg} / \mathrm{L} \\
95_{\mathrm{Zr}} \mathrm{MBq} / \mathrm{L} \\
95_{\mathrm{Nb}} \mathrm{MBq} / \mathrm{L} \\
103_{\mathrm{Ru}} \mathrm{MBq} / \mathrm{L} \\
106_{\mathrm{Ru}} \mathrm{MBq} / \mathrm{L} \\
125 \mathrm{Sb}, \mathrm{MBq} / \mathrm{L} \\
13{ }^{4} \mathrm{Cs}, \mathrm{MBq} / \mathrm{L} \\
137 \mathrm{Cs}, \mathrm{MBq} / \mathrm{L} \\
141 \mathrm{Ce}, \mathrm{MBq} / \mathrm{L} \\
144_{\mathrm{Ce}} \mathrm{MBq} / \mathrm{L} \\
154_{\mathrm{Eu}} \mathrm{MBq} / \mathrm{L} \\
155_{\mathrm{Eu}} \mathrm{MBq} / \mathrm{L}\end{array}$ & $\begin{array}{l}0.10 \\
37 \\
0.44 \\
0.127 \\
1.28 \\
1.42 \\
<0.04 \\
0.0104 . \\
<0.1 \\
<0.01 \\
<0.06\end{array}$ \\
\hline
\end{tabular}


Table A-5. Selective uranium extraction, bank conditions and results

Run No.

8-3

Dates

Bank temperature, ${ }^{\circ} \mathrm{C}$

Number of stages

Scrub/acid addition/extraction

HCX stream flow rate, L/h

Flow ratios

$\mathrm{HCS} / \mathrm{HCX}$

HCIS /HCX

HBP / HCX

Inlet stream compositions

HCS stream

$\mathrm{HNO}_{3}, \mathrm{~mol} / \mathrm{L}$

$\mathrm{HAN}$, mol/L

$\mathrm{N}_{2} \mathrm{H}_{4}, \mathrm{~mol} / \mathrm{L}$

HCIS stream, $\mathrm{HNO}_{3}, \mathrm{~mol} / \mathrm{L}$

HCX stream, \% TBP

HBP stream

$\mathrm{HNO}_{3}, \mathrm{~mol} / \mathrm{L}$

$\mathrm{U}, \mathrm{g} / \mathrm{L}$

$\mathrm{Pu}, \mathrm{g} / \mathrm{L}$

$23{ }^{7} \mathrm{~Np}$, mg/L

$95 \mathrm{Zr}, \mathrm{MBq} / \mathrm{L}$

$95 \mathrm{Nb}, \mathrm{MBq} / \mathrm{L}$

$103_{\mathrm{Ru}}, \mathrm{MBq} / \mathrm{L}$

$106 \mathrm{Ru}, \mathrm{MBq} / \mathrm{L}$

$125 \mathrm{Sb}, \mathrm{MBq} / \mathrm{L}$

$13{ }^{4} \mathrm{Cs}, \mathrm{MBq} / \mathrm{L}$

$137 \mathrm{Cs}, \mathrm{MBq} / \mathrm{L}$

${ }^{141} \mathrm{Ce}, \mathrm{MBq} / \mathrm{L}$

$144 \mathrm{Ce}, \mathrm{MBq} / \mathrm{L}$

$15{ }^{4} \mathrm{Eu}, \mathrm{MBq} / \mathrm{L}$

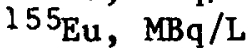

$5 / 16-17 / 84$

26

$8 / 1 / 7$

0.983

0.18

0.15

1.12

0.50

0.10

0.03

8.0

$30.0 \pm 0.5$

0.2

59

12

$<0.2$

0.82

12

$<0.03$

0.72

$<0.08$

$<0.03$

0.15

0.60

$<0.03$

$<0.08$ 
Table A-5 (continued)

Run No.

8-3

Outlet stream compositions

HCW stream

$\mathrm{HNO}_{3}, \mathrm{~mol} / \mathrm{L}$

$\mathrm{U}, \mathrm{g} / \mathrm{L}$

$\mathrm{Pu}, \mathrm{mg} / \mathrm{L}$

$95 \mathrm{Zr}, \mathrm{MBq} / \mathrm{L}$

$95_{\mathrm{Nb}}, \mathrm{MBq} / \mathrm{L}$

$103 \mathrm{Ru}, \mathrm{MBq} / \mathrm{L}$

$10{ }^{6} \mathrm{Ru}, \mathrm{MBq} / \mathrm{L}$

$125 \mathrm{Sb}, \mathrm{MBq} / \mathrm{L}$

$13{ }^{4} \mathrm{Cs}, \mathrm{MBq} / \mathrm{L}$

$137 \mathrm{Cs}, \mathrm{MBq} / \mathrm{L}$

$14 \mathrm{l} \mathrm{Ce}, \mathrm{MBq} / \mathrm{L}$

$144 \mathrm{Ce}, \mathrm{MBq} / \mathrm{L}$

$154 \mathrm{Eu}, \mathrm{MBq} / \mathrm{L}$

$155^{\mathrm{Eu}}, \mathrm{MBq} / \mathrm{L}$

$$
\begin{aligned}
& 0.04 \\
& 55.4 \\
& 0.5 \\
& <0.04 \\
& 0.022 \\
& \\
& 0.076 \\
& <0.02 \\
& <0.01 \\
& 0.132 \\
& <0.02 \\
& <0.06
\end{aligned}
$$

\section{HCP stream}

$\mathrm{HNO}_{3}, \mathrm{~mol} / \mathrm{L}$

$\mathrm{U}, \mathrm{mg} / \mathrm{L}$

$\mathrm{Pu}, \mathrm{g} / \mathrm{L}$

$23^{7} \mathrm{~Np}, \mathrm{mg} / \mathrm{L}$

${ }^{95} \mathrm{Zr}, \mathrm{MBq} / \mathrm{L}$

$95 \mathrm{Nb}, \mathrm{MBq} / \mathrm{L}$

$103 \mathrm{Ru}, \mathrm{MBq} / \mathrm{L}$

$106_{\mathrm{Ru}}, \mathrm{MBq} / \mathrm{L}$

$125 \mathrm{Sb}, \mathrm{MBq} / \mathrm{L}$

$13{ }^{4} \mathrm{Cs}, \mathrm{MBq} / \mathrm{L}$

$137 \mathrm{Cs}, \mathrm{MBq} / \mathrm{L}$

$141 \mathrm{Ce}, \mathrm{MBq} / \mathrm{L}$

${ }^{144} \mathrm{Ce}, \mathrm{MBq} / \mathrm{L}$

$154 \mathrm{Eu}, \mathrm{MBq} / \mathrm{L}$

$155_{\mathrm{Eu}}, \mathrm{MBq} / \mathrm{L}$

\subsection{7}

$<1$

10.3

$<0.2$

3.71

10.9

$<0.09$

0.896

$<0.08$

$<0.05$

0.075

$<0.1$

$<0.05$

$<0.08$ 
INTERNAL DISTRIBUTION

$\begin{aligned} \text { 1. } & \text { J. T. Bell } \\ 2-6 . & \text { D. E. Benker } \\ 7-11 . & \text { J. E. Bigelow } \\ 12 . & \text { J. O. Blomeke } \\ \text { 13-17. } & \text { W. D. Bond } \\ \text { 18-20. } & \text { W. D. Burch } \\ 21 . & \text { D. O. Campbe11 } \\ \text { 22-26. } & \text { F. R. Chattin } \\ 27 . & \text { D. A. Costanzo } \\ 28 . & \text { R. M. Counce } \\ 29 . & \text { S. F. DeMuth } \\ 30 . & \text { R. D. Ehrlich } \\ 31 . & \text { M. J. Feldman } \\ 32 . & \text { R. L. Fellows } \\ 33 . & \text { R. W. Glass } \\ 34 . & \text { W. S. Groenier } \\ 35 . & \text { P. A. Haas } \\ 36 . & \text { D. C. Hampson } \\ 37 . & \text { J. R. Hightower } \\ 38 . & \text { E. K. Johnson } \\ 39 . & \text { R. T. Jubin } \\ 40 . & \text { M. V. Keigan } \\ 44-45 . & \text { L. J. King } \\ 46-49 . & \text { F. G. K1tts } \\ 50 . & \text { L. N. Klatt } \\ 51 . & \text { E. H. Krieg, Jr. } \\ 52 . & \text { L. D. Ladd }\end{aligned}$

\author{
53. R. E. Leuze \\ 54. J. C. Mallen \\ 55. S. A. Meacham \\ 56. D. R. Moser \\ 57. M. J. Rohr \\ 58-62. R. G. Ross \\ 63. F. M. Scheitlin \\ 64. M. B. Sears \\ 65. J. H. Shaffer \\ 66. R. W. Sharpe \\ 67. G. R. Smolen \\ 68. B. B. Spencer \\ 69-73. R. G. Stacy \\ 74. M. G. Stewart \\ 75. J. G. Stradley \\ 76. V. C. A. Vaughen \\ 77. T. D. Welch \\ 78. M. E. What ley \\ 79. R. G. Wymer \\ 80. 0. O. Yarbro \\ 81. Central Research Library \\ 82. ORNL-Y-12 Technical Lib. \\ Document Reference Section \\ 83-84. Laboratory Records \\ 85. Laboratory Records, ORNL R.C. \\ 86. ORNL Patent Section
}

\section{EXTERNAL DISTRIBUTION}

87. K. 0. Laughon, Jr., Director, Office of Spent Fuel Management and Reprocessing Systems, U.S. Department of Energy, Washington, DC 20545

88-69. D. E. Bailey, Director, Division of LMFBR Fuel Cycle Projects, U.S. Department of Energy, Washington, DC 20545

90. F. P. Baranowski, 1110 Dapple Grey Court, Great Falls, VA 22066

91. S. J. Beard, Vice President, Marketing and Uranium Operations, Exxon Nuclear Company, Inc., 600 108th Avenue, N.E., C-00777, Bellevue, WA 98009

92. R. Little, Princeton Plasma Physics Laboratory, James Forresta1 Campus, P.0. Box 451, Princeton, NJ 08544

93. J. L. McElroy, Pacific Northwest Laboratories, P.0. Box 999, Richland, WA 99352

94. M. J. Ohantan, Assoctate Dean for Research, College of Engineering, 300 Weil Ha11, University of Florida, Gainesville, FL 32611

95. J. F. Proctor, Senior Technical Specialist, E.I. duPont deNemours \& Company, Savannah River Laboratory, Aiken, SC 29801

96. Office of Assistant Manager for Energy Research and Development, DOE-ORO, P.O. Box E, Oak Ridge, TN 37831

97-142. Given distribution as shown in TIC-4500 under UC-86T, Consolidated Fuel Reprocessing Category (Applied) 